\title{
INTRODUCTORY NOTE TO APPLICATION OF THE INTERNATIONAL CONVENTION ON THE ELIMINATION OF ALL FORMS OF RACIAL DISCRIMINATION (QATAR V. UNITED ARAB EMIRATES): REQUEST FOR THE INDICATION OF PROVISIONAL MEASURES (I.C.J.) BY ALEXANDRA HOFER*
}

[July 23, 2018]

\section{Introduction}

On July 23, 2018, the International Court of Justice (ICJ or Court) issued its Order on Qatar's request for provisional measures in the Qatar v. United Arab Emirates (UAE) case in which Qatar claims the UAE is responsible for violating the Convention on the Elimination of All Forms of Racial Discrimination (CERD or the Convention). ${ }^{1}$ The Court has previously ordered provisional measures under CERD in the context of the Ukraine v. Russia case $^{2}$ and in the Georgia v. Russia proceedings. ${ }^{3}$ As is already apparent in the Order and the dissenting and separate opinions, the Qatar v. UAE case raises important issues pertaining to the interpretation of racial discrimination on the basis of "national origin" under Article 1(1) CERD as well as to the reading of the procedural conditions under Article 22 CERD. ${ }^{4}$

\section{Background}

Qatar initiated proceedings against the United Arab Emirates (UAE) under CERD and submitted its request for provisional measures to the Court on June 11, 2018. ${ }^{5}$ The complaint before the ICJ is the latest in a series of attempts by the Qatari government to challenge the legality of measures adopted against it by Saudi Arabia, the UAE, Bahrain, and Egypt (the Quartet) on June 5, 2017. On that date, in support of Bahrain and Saudi Arabia, the UAE announced that it was breaking off diplomatic relations with Qatar, that Qatari residents were prevented from entering UAE territory, that Qatari nationals were given fourteen days to leave the UAE, and that it was closing the use of the UAE's airspace and seaports to Qataris and Qatari means of transportation. ${ }^{6}$ Additional measures have been adopted since then, notably against the Qatari news outlet Al-Jazeera.

The UAE is the only state among the Quartet to not have made a reservation against CERD Article 22, which allows state parties to submit a dispute with respect to the interpretation or application of the Convention before the ICJ. Prior to submitting the dispute to the ICJ, the parties must attempt to reach a resolution "by negotiation or by the procedures expressly provided for in [the] Convention," in particular submitting a communication to the Committee on the Elimination of Racial Discrimination (the Committee) pursuant to CERD Article 11.

According to Qatar's application instituting proceedings, discrimination on the basis of nationality is encompassed in CERD Article 1(1), which prohibits acts of discrimination based on an individual's "national origin." This reading would be confirmed by CERD Committee recommendation XXX. ${ }^{7}$ Qatar claims that by collectively expelling Qatari nationals, the UAE is violating their basic human rights solely on the basis of their nationality in breach of CERD Articles 2 and 5. The UAE would also be in breach of Articles 4 and 7 by inciting anti-Qatari racial discrimination and hate speech. Finally, in failing to provide effective judicial protection and remedies, the UAE would be responsible for violating CERD Article 6. Qatar thus requested provisional measures to prevent further, irreparable harm and to prevent the aggravation or extension of the dispute. In its oral arguments, the UAE countered that CERD Article 1(1) does not encompass discrimination on the basis of nationality ${ }^{8}$ and that Qatar's interpretation of the rights enshrined in CERD Article 5 is too broad. ${ }^{9}$ The UAE also argued that Qatar has not provided sufficient evidence to substantiate its claims under CERD, stating that there is no policy to expel Qatari nationals or to separate UAE-Qatari families. ${ }^{10}$

\section{The Court's Decision}

In order to grant provisional measures, the Court needs to be satisfied that it has prima facie jurisdiction, that the rights claimed by the applicant are plausible, that there is a link between the rights whose protection is sought and the requested provisional measures, and that there is a real and imminent risk that irreparable prejudice will 
be caused to those rights. The bench found these conditions were met, albeit by a split vote. By eight votes against seven, the judges granted three of the nine provisional measures requested by Qatar. It essentially ordered the UAE to reunite families that had been separated following the statement of June 5, 2017, to allow Qatari students to pursue their education in the UAE, and to enable Qataris affected by the measures to have access to tribunals and other judicial institutions. By eleven votes to four, the Court indicated that "both Parties shall refrain from any action which might aggravate or extend the dispute before the Court or make it more difficult to resolve."

The Court first established that it had prima facie jurisdiction under Article 22 of the Convention. There was a dispute between Qatar and the UAE on the interpretation and application of CERD ${ }^{11}$ and at least one of the procedural conditions provided under Article 22 had been met; that was the attempt to solve the dispute through negotiation. ${ }^{12}$ An issue that arose in Ukraine v. Russia and that surfaced during the present proceedings was whether the procedural conditions under CERD Article 22 are cumulative or alternative. During the oral pleadings, the UAE contended that the conditions should be understood as cumulative. Although Qatar had submitted a communication to the Committee pursuant to Article $11,{ }^{13}$ during the hearings it submitted that the conditions in Article 22 are alternative. It is anticipated that the ICJ will provide clarity on the matter in the Ukraine v. Russia preliminary objections judgment, which will be delivered prior to the preliminary objections phase in Qatar v. UAE, and that this will influence the claims put forward by Qatar and the UAE. It remains to be seen during the preliminary objections phase whether Qatar's current communication to the Committee will impede the Court's jurisdiction, an argument raised by the UAE during the oral proceedings. ${ }^{14}$

The majority found that the measures announced June 5, 2017, only target Qatari nationals living in the UAE and that no account was taken of individual circumstances of Qatari residents living in the UAE. Thus, some of the rights asserted in CERD Article 5 are plausible, for example "the alleged racial discrimination in the enjoyment of rights such as the right to marriage and to choice of spouse, the right to education, as well as freedom of movement, and access to justice." ${ }^{15}$ However, the dissenting judges contested this and argued that in CERD Article 1(1) the definition of racial discrimination and the Committee's General Recommendation 30 do not encompass discrimination on the basis of nationality. Based on this interpretation of "national origin," the dispute would fall outside the scope of CERD and the rights Qatar claims would not be plausible. ${ }^{16}$ In the Order, the Court notes the disagreement on the matter of "national origin" and defers a decision on the question until later in the proceedings. ${ }^{17}$ The dissenting judges also found that Qatar's claims failed on the facts. They were not convinced that Qatar provided sufficient evidence that the measures announced on June 5, 2017, were put into effect. Under these conditions there was no risk of irreparable prejudice, nor was there urgency, ${ }^{18}$ contrary to what the majority decided. ${ }^{19}$

\section{Conclusion}

The Qatar v. UAE Order is the third instance where the ICJ indicated provisional measures under CERD. As the outcome of the Georgia v. Russia preliminary objections judgment of April 1, 2011, demonstrates ${ }^{20}$ the indication of provisional measures does not mean the Court will rule in the preliminary objections stage that they may hear the merits of the case. In addition to the debate regarding the interpretation of the procedural conditions under CERD Article 22, the issues raised by the dissenting and separate opinions highlight the multiple challenges Qatar's application to the ICJ faces as the proceedings move forward.

\section{ENDNOTES}

1 Application of the International Convention on the Elimination of All Forms of Racial Discrimination (Qatar v. UAE), Order on Provisional Measures (July 23, 2018), https:/www.icj-cij.org/en/case/172/orders [hereinafter Order].

2 Application of the International Convention for the Suppression of the Financing of Terrorism and of the International Convention on the Elimination of All Forms of Racial
Discrimination (Ukraine v. Russian Federation), Order on Provisional Measures, 2017 ICJ REP. 104 (April 19).

3 Application of the International Convention on the Elimination of All Forms of Racial Discrimination (Georgia v. Russian Federation), Order on Provisional Measures, 2008 ICJ Rep. 353 (Oct. 15).

4 Convention on the Elimination of All Forms of Racial Discrimination, Jan. 4, 1969, 660 UNTS 212. 
5 Application of the International Convention on the Elimination of All Forms of Racial Discrimination (Qatar v. UAE), Application Instituting Proceedings (June 11, 2018), https:// www.icj-cij.org/files/case-related/172/172-20180611-APP-0100-EN.pdf [hereinafter Application Instituting Proceedings]; Application of the International Convention on the Elimination of All Forms of Racial Discrimination (Qatar v. UAE), Request for the Indication of Provisional Measures (June 11, 2018), https://www.icj-cij.org/files/case-related/172/17220180611-WRI-01-00-EN.pdf.

6 UAE Ministry of Foreign Affairs Press Release, UAE Supports Statements of Kingdom of Bahrain and Kingdom of Saudi Arabia on Qatar (June 5, 2017), https://www.mofa.gov.ae/EN/ MediaCenter/News/Pages/05-06-2017-UAE-Qatar.aspx.

7 UN Committee on the Elimination of Racial Discrimination, CERD General Recommendation XXX on Discrimination Against Non-Citizens (Oct. 1, 2002), http://www.refworld. org/docid/45139e084.html.

8 Application of the International Convention on the Elimination of All Forms of Racial Discrimination (Qatar v. UAE), Verbatim Record of the Oral Hearings, 40-48 (June 28, 2018), https://www.icj-cij.org/files/case-related/172/172-20180628-ORA01-00-BI.pdf [hereinafter Oral Hearings].

Id. at $51-53$.
10 Id. at $10-11,63-65$.

11 Order, supra note 1, $\mathbf{\uparrow \uparrow} 14-28$.

12 Id. ๆ 36-38.

13 Application Instituting Proceedings, supra note 5, at 14 n.28.

14 Oral Hearings, supra note 8, at 26-27.

15 Order, supra note 1, $₫ 54$.

16 Order, supra note 1, Joint Declaration of Judges Tomka, Gaja and Gevorgian; Dissenting Opinion of Judge Crawford; Opinion Dissidente de M. le Juge Salam.

17 Order, supra note 1, $₫ 27$.

18 Order, supra note 1, Dissenting Opinion of Judge Bhandari; Dissenting Opinion of Judge Crawford.

19 Order, supra note 1, 99 67-71.

20 Where the ICJ concluded that the procedural conditions under Article 22 CERD were not met, Application of the International Convention on the Elimination of All Forms of Racial Discrimination (Georgia v. Russian Federation), Judgment on Preliminary Objections (April 1, 2011), https://www. icj-cij.org/files/case-related/140/140-20110401-JUD-01-00-EN. pdf. 


\section{APPLICATION OF THE INTERNATIONAL CONVENTION ON THE ELIMINATION OF ALL FORMS OF RACIAL DISCRIMINATION (QATAR V. UNITED ARAB EMIRATES): REQUEST FOR THE \\ INDICATION OF PROVISIONAL MEASURES (I.C.J.)*}

[July 23, 2018]

\section{INTERNATIONAL COURT OF JUSTICE}

YEAR 2018

2018

23 July

General List

No. 172

23 July 2018

\section{APPLICATION OF THE INTERNATIONAL CONVENTION ON THE ELIMINATION OF ALL FORMS OF RACIAL DISCRIMINATION}

(QATAR v. UNITED ARAB EMIRATES)

REQUEST FOR THE INDICATION OF PROVISIONAL MEASURES

\section{ORDER}

Present: President YUSUF; Vice-President XUE; Judges TOMKA, ABRAHAM, BENNOUNA, CANÇADO TRINDADE, GAJA, SEBUTINDE, BHANDARI, ROBINSON, CRAWFORD, GEVORGIAN, SALAM; Judges ad hoc COT, DAUDET; Registrar COUVREUR.

The International Court of Justice,

Composed as above,

After deliberation,

Having regard to Articles 41 and 48 of the Statute of the Court and Articles 73, 74 and 75 of the Rules of Court,

Makes the following Order:

Whereas:

1. On 11 June 2018, the State of Qatar (hereinafter referred to as "Qatar") filed in the Registry of the Court an Application instituting proceedings against the United Arab Emirates (hereinafter referred to as the "UAE") with regard to alleged violations of the International Convention on the Elimination of All Forms of Racial Discrimination of 21 December 1965 (hereinafter "CERD" or the "Convention").

2. At the end of its Application, Qatar

"in its own right and as parens patriae of its citizens, respectfully requests the Court to adjudge and declare that the UAE, through its State organs, State agents, and other persons and entities exercising governmental authority, and through other agents acting on its instructions or under its direction and control, has violated its obligations under Articles 2, 4, 5, 6, and 7 of the CERD by taking, inter alia, the following unlawful actions: 
(a) Expelling, on a collective basis, all Qataris from, and prohibiting the entry of all Qataris into, the $\mathrm{UAE}$ on the basis of their national origin;

(b) Violating other fundamental rights, including the rights to marriage and choice of spouse, freedom of opinion and expression, public health and medical care, education and training, property, work, participation in cultural activities, and equal treatment before tribunals;

(c) Failing to condemn and instead encouraging racial hatred against Qatar and Qataris and failing to take measures that aim to combat prejudices, including by inter alia: criminalizing the expression of sympathy toward Qatar and Qataris; allowing, promoting, and financing an international antiQatar public and social media campaign; silencing Qatari media; and calling for physical attacks on Qatari entities; and

(d) Failing to provide effective protection and remedies to Qataris to seek redress against acts of racial discrimination through UAE courts and institutions."

Accordingly,

"Qatar respectfully requests the Court to order the UAE to take all steps necessary to comply with its obligations under CERD and, inter alia:

(a) Immediately cease and revoke the Discriminatory Measures, including but not limited to the directives against 'sympathizing' with Qataris, and any other national laws that discriminate de jure or de facto against Qataris on the basis of their national origin;

(b) Immediately cease all other measures that incite discrimination (including media campaigns and supporting others to propagate discriminatory messages) and criminalize such measures;

(c) Comply with its obligations under the CERD to condemn publicly racial discrimination against Qataris, pursue a policy of eliminating racial discrimination, and adopt measures to combat such prejudice;

(d) Refrain from taking any further measures that would discriminate against Qataris within its jurisdiction or control;

(e) Restore rights of Qataris to, inter alia, marriage and choice of spouse, freedom of opinion and expression, public health and medical care, education and training, property, work, participation in cultural activities, and equal treatment before tribunals, and put in place measures to ensure those rights are respected;

(f) Provide assurances and guarantees of non-repetition of the UAE's illegal conduct; and

(g) Make full reparation, including compensation, for the harm suffered as a result of the UAE's actions in violation of the CERD."

3. In its Application, Qatar seeks to found the Court's jurisdiction on Article 36, paragraph 1, of the Statute of the Court and on Article 22 of CERD.

4. On 11 June 2018, Qatar also submitted a Request for the indication of provisional measures, referring to Article 41 of the Statute and to Articles 73, 74 and 75 of the Rules of Court.

5. At the end of its Request for the indication of provisional measures, Qatar asked the Court to indicate the following provisional measures:

(a) The UAE shall cease and desist from any and all conduct that could result, directly or indirectly, in any form of racial discrimination against Qatari individuals and entities by any organs, agents, persons, and entities exercising UAE governmental authority in its territory, or under its direction 
or control. In particular, the UAE shall immediately cease and desist from violations of the human rights of Qataris under the CERD, including by:

(i) suspending operation of the collective expulsion of all Qataris from, and ban on entry into, the $\mathrm{UAE}$ on the basis of national origin;

(ii) taking all necessary steps to ensure that Qataris (or persons with links to Qatar) are not subjected to racial hatred or discrimination, including by condemning hate speech targeting Qataris, ceasing publication of anti-Qatar statements and caricatures, and refraining from any other incitement to racial discrimination against Qataris;

(iii) suspending the application of its Federal Decree-Law no. (5) of 2012, On Combatting Cybercrimes, to any person who 'shows sympathy ... towards Qatar' and any other domestic laws that (de jure or de facto) discriminate against Qataris;

(iv) taking the measures necessary to protect freedom of expression of Qataris in the UAE, including by suspending the UAE's closure and blocking of transmissions by Qatari media outlets;

(v) ceasing and desisting from measures that, directly or indirectly, result in the separation of families that include a Qatari, and taking all necessary steps to ensure that families separated by the Discriminatory Measures are reunited (in the UAE, if that is the family's preference);

(vi) ceasing and desisting from measures that, directly or indirectly, result in Qataris being unable to seek medical care in the UAE on the grounds of their national origin and taking all necessary steps to ensure that such care is provided;

(vii) ceasing and desisting from measures that, directly or indirectly, prevent Qatari students from receiving education or training from UAE institutions, and taking all necessary steps to ensure that students have access to their educational records;

(viii) ceasing and desisting from measures that, directly or indirectly, prevent Qataris from accessing, enjoying, utilizing, or managing their property in the UAE, and taking all necessary steps to ensure that Qataris may authorize valid powers of attorney in the UAE, renew necessary business and worker licenses, and renew their leases; and

(ix) taking all necessary steps to ensure that Qataris are granted equal treatment before tribunals and other judicial organs in the UAE, including a mechanism to challenge any discriminatory measures.

(b) The UAE shall abstain from any measure that might aggravate, extend, or make more difficult resolution of this dispute; and

(c) The UAE shall abstain from any other measure that might prejudice the rights of Qatar in the dispute before the Court."

6. The Registrar immediately communicated to the Government of the UAE the Application, in accordance with Article 40, paragraph 2, of the Statute of the Court, and the Request for the indication of provisional measures, in accordance with Article 73, paragraph 2, of the Rules of Court. He also notified the Secretary-General of the United Nations of the filing of the Application and the Request by Qatar.

7. Pending the notification provided for by Article 40, paragraph 3, of the Statute by transmission of the printed bilingual text of the Application to the Members of the United Nations through the Secretary-General, the Registrar informed those States of the filing of the Application and the Request.

8. Since the Court included upon the Bench no judge of the nationality of either Party, each Party proceeded to exercise the right conferred upon it by Article 31 of the Statute to choose a judge ad hoc to sit in the case. Qatar chose Mr. Yves Daudet and the UAE Mr. Jean-Pierre Cot. 
9. By letters dated 14 June 2018, the Registrar informed the Parties that, pursuant to Article 74, paragraph 3, of its Rules, the Court had fixed 27, 28 and 29 June 2018 as the dates for the oral proceedings on the Request for the indication of provisional measures.

10. At the public hearings, oral observations on the request for the indication of provisional measures were presented by:

On behalf of Qatar: $\quad$ Mr. Mohammed Abdulaziz Al-Khulaifi,

Mr. Donald Francis Donovan,

Ms Catherine Amirfar,

Mr. Pierre Klein,

Lord Peter Goldsmith,

Mr. Lawrence H. Martin.

On behalf of the UAE: $\quad$ H.E. Mr. Saeed Ali Yousef Alnowais,

Mr. Alain Pellet,

Mr. Tullio Treves,

Mr. Simon Olleson,

Mr. Malcolm Shaw,

Mr. Charles L.O. Buderi.

11. At the end of its second round of oral observations, Qatar asked the Court to indicate the following provisional measures:

(a) The UAE shall cease and desist from any and all conduct that could result, directly or indirectly, in any form of racial discrimination against Qatari individuals and entities by any organs, agents, persons, and entities exercising UAE governmental authority in its territory, or under its direction or control. In particular, the UAE shall immediately cease and desist from violations of the human rights of Qataris under the CERD, including by:

(i) suspending operation of the collective expulsion of all Qataris from, and ban on entry into, the $\mathrm{UAE}$ on the basis of national origin;

(ii) taking all necessary steps to ensure that Qataris (or persons with links to Qatar) are not subjected to racial hatred or discrimination, including by condemning hate speech targeting Qataris, ceasing publication of anti-Qatar statements and caricatures, and refraining from any other incitement to racial discrimination against Qataris;

(iii) suspending the application of its Federal Decree Law No. (5) of 2012, On Combatting Cybercrimes, to any person who 'shows sympathy ... towards Qatar' and any other domestic laws that (de jure or de facto) discriminate against Qataris;

(iv) taking the measures necessary to protect freedom of expression of Qataris in the UAE, including by suspending the UAE's closure and blocking of transmissions by Qatari media outlets;

(v) ceasing and desisting from measures that, directly or indirectly, result in the separation of families that include a Qatari, and taking all necessary steps to ensure that families separated by the Discriminatory Measures are reunited (in the UAE, if that is the family's preference);

(vi) ceasing and desisting from measures that, directly or indirectly, result in Qataris being unable to seek medical care in the UAE on the grounds of their national origin and taking all necessary steps to ensure that such care is provided; 
(vii) ceasing and desisting from measures that, directly or indirectly, prevent Qatari students from receiving education or training from UAE institutions, and taking all necessary steps to ensure that students have access to their educational records;

(viii) ceasing and desisting from measures that, directly or indirectly, prevent Qataris from accessing, enjoying, utilizing, or managing their property in the UAE, and taking all necessary steps to ensure that Qataris may authorize valid powers of attorney in the UAE, renew necessary business and worker licenses, and renew their leases; and

(ix) taking all necessary steps to ensure that Qataris are granted equal treatment before tribunals and other judicial organs in the UAE, including a mechanism to challenge any discriminatory measures.

(b) The UAE shall abstain from any measure that might aggravate, extend, or make more difficult resolution of this dispute; and

(c) The UAE shall abstain from any other measure that might prejudice the rights of Qatar in the dispute before the Court."

12. At the end of its second round of oral observations, the UAE requested the Court "to reject the request for the indication of provisional measures submitted by the State of Qatar".

13. At the hearings, Members of the Court put questions to the Parties, to which replies were given in writing, in accordance with Article 61, paragraph 4, of the Rules of Court. Under Article 72 of the Rules of Court, each Party presented written comments on the written replies received from the other.

\section{PRIMA FACIE JURISDICTION}

\section{GeNeral INTRODUCTION}

14. The Court may indicate provisional measures only if the provisions relied on by the Applicant appear, prima facie, to afford a basis on which its jurisdiction could be founded, but need not satisfy itself in a definitive manner that it has jurisdiction as regards the merits of the case (see, for example, Jadhav (India v. Pakistan), Provisional Measures, Order of 18 May 2017, I.C.J. Reports 2017, p. 236, para. 15).

15. In the present case, Qatar seeks to found the jurisdiction of the Court on Article 36, paragraph 1, of the Statute of the Court and on Article 22 of CERD (see paragraph 3 above). The Court must therefore first determine whether those provisions prima facie confer upon it jurisdiction to rule on the merits of the case, enabling it - if the other necessary conditions are fulfilled - to indicate provisional measures.

16. Qatar and the UAE are parties to CERD. Qatar acceded to that instrument on 22 July 1976, without entering any reservation; the UAE did so on 20 June 1974, without entering a reservation to Article 22 or any other relevant reservation for the present purposes.

17. Article 22 of CERD provides that:

"Any dispute between two or more States Parties with respect to the interpretation or application of this Convention, which is not settled by negotiation or by the procedures expressly provided for in this Convention, shall, at the request of any of the parties to the dispute, be referred to the International Court of Justice for decision, unless the disputants agree to another mode of settlement." 


\section{EXISTENCE OF A DISPUTE CONCERNING THE INTERPRETATION OR APPLICATION OF CERD}

18. Article 22 of CERD makes the Court's jurisdiction conditional on the existence of a dispute arising out of the interpretation or application of CERD. A dispute between States exists where they hold clearly opposite views concerning the question of the performance or non-performance of certain international obligations (see Application of the International Convention for the Suppression of the Financing of Terrorism and of the International Convention on the Elimination of All Forms of Racial Discrimination (Ukraine v. Russian Federation), Provisional Measures, Order of 19 April 2017, I.C.J. Reports 2017, p. 115, para. 22, citing Interpretation of Peace treaties with Bulgaria, Hungary and Romania, First Phase, Advisory Opinion, I.C.J. Reports 1950, p. 74). The claim of one party must be "positively opposed" by the other (South West Africa (Ethiopia v. South Africa; Liberia v. South Africa), Preliminary Objections, Judgment, I.C.J. Reports 1962, p. 328). In order to determine whether a dispute exists, the Court "cannot limit itself to noting that one of the Parties maintains that the Convention applies, while the other denies it" (Immunities and Criminal Proceedings (Equatorial Guinea v. France), Provisional Measures, Order of 7 December 2016, I.C.J. Reports 2016 (II), p. 1159, para. 47). Since Qatar has invoked as a basis of the Court's jurisdiction the compromissory clause in an international convention, the Court must ascertain whether "the acts complained of by [the Applicant] are prima facie capable of falling within the provisions of that instrument and ... [whether,] as a consequence, the dispute is one which the Court has jurisdiction ratione materiae to entertain" (ibid.).

19. Qatar contends that a dispute exists between the Parties concerning the interpretation and application of CERD. It asserts that, beginning on 5 June 2017, the UAE took discriminatory measures against Qataris and their families in violation of the provisions and principles underlying CERD. More specifically, Qatar states that, on 5 June 2017, the UAE "expelled all Qataris within its territory, giving them only 14 days to leave" and that it continues to prohibit Qataris from entering the UAE. Qatar observes that such measures do not apply to other non-citizens residing in the UAE. It therefore contends that the Respondent has targeted Qataris on the basis of their national origin, in violation of Article 1, paragraph 1, of CERD. Relying, inter alia, on General Recommendation XXX of the CERD Committee, Qatar argues that the Convention applies to discriminatory conduct based on Qatari national origin or nationality.

20. According to Qatar, because of the measures taken by the UAE, "[t]housands of Qataris are unable to return to the UAE, are separated from their families there, and are losing their homes, their jobs, their property, access to medical care, and the opportunity to pursue their education". It adds that there is no opportunity for Qataris to seek justice for these violations. The Applicant thus submits that the UAE is interfering with Qataris' basic human rights under Articles 2 and 5 of CERD. More specifically, it contends that the Respondent is violating — vis-à-vis Qataris - their right to marriage and choice of spouse; their right to freedom of opinion and expression; their right to public health and medical care; their right to education and training; their right to property; their right to work and their right to equal treatment before tribunals.

21. Qatar also maintains that the UAE has violated its obligations under Articles 4 and 7 of CERD "by failing to condemn racial hatred and prejudice and by inciting such hatred and prejudice against Qatar and Qataris". It further asserts that the UAE has failed to provide Qataris within its jurisdiction with effective protection and remedies against acts of racial discrimination, in violation of Article 6 of CERD.

22. The UAE contends that there is no dispute between the Parties concerning the interpretation or application of CERD. It states that there has been no mass expulsion of Qataris from the UAE, that all Qataris in the UAE continue to enjoy the full rights granted by law to all residents of or visitors to the country and that Qataris live with their families, attend school, and have access to health care as well as government services. The UAE explains that the measures it adopted in June 2017 were "to impose additional requirements on the entry or re-entry into [its] territory by Qatari nationals".

23. The UAE further contends that no Qatari citizens have been prevented from seeking legal remedies for any matter and that there has been no interference in the business affairs of Qatari nationals. The UAE maintains that it 
has not engaged in any media campaign against Qataris based on their nationality. Moreover, according to the UAE, there is no dispute falling within the scope of CERD as regards any alleged interference with freedom of expression.

24. In addition, the UAE asserts that, "even taking the factual allegations made by Qatar at face value", those allegations do not concern prohibited "racial" discrimination as defined in the Convention or other prohibited measures falling within the scope of the Convention. The UAE considers that the term "national origin" in Article 1, paragraph 1, of CERD is "twinned with" "ethnic origin" and that "national origin" is not to be read as encompassing "present nationality". It explains that such an interpretation flows from the ordinary meaning of that provision, when read in its context and in light of the object and purpose of the Convention. The UAE also considers that its interpretation is confirmed by the travaux préparatoires. It thus argues that Qatar's claims relating to alleged differences of treatment of Qatari nationals based solely on their present nationality fall outside the scope ratione materiae of CERD.

25. The Court considers that, as evidenced by the arguments advanced and the documents placed before it, the Parties differ on the nature and scope of the measures taken by the UAE beginning on 5 June 2017 as well as on the question whether they relate to rights and obligations under CERD. Paragraph 2 of the statement made by the UAE on 5 June 2017 envisages the following measures:

"Preventing Qatari nationals from entering the UAE or crossing its points of entry, giving Qatari residents and visitors in the UAE 14 days to leave the country for precautionary security reasons.

The UAE nationals are likewise banned from traveling to or staying in Qatar or transiting through its territories."

26. The Court notes that Qatar contends that the measures adopted by the UAE purposely targeted Qataris based on their national origin. Consequently, according to Qatar, the UAE has failed to respect its obligations under Articles 2, 4, 5, 6 and 7 of CERD. The Court observes that Qatar maintains in particular that, because of the measures taken on 5 June 2017, UAE-Qatari mixed families have been separated, medical care has been suspended for Qataris in the UAE, depriving those who were under medical treatment from receiving further medical assistance, Qatari students have been deprived of the opportunity to complete their education in the UAE and to continue their studies elsewhere since UAE universities have refused to provide them with their educational records, and Qataris have not been granted equal treatment before tribunals and other judicial organs in the UAE. For its part, the UAE firmly denies that it has committed any of the violations set out above.

27. In the Court's view, the acts referred to by Qatar, in particular the statement of 5 June 2017 — which allegedly targeted Qataris on the basis of their national origin - whereby the UAE announced that Qataris were to leave its territory within 14 days and that they would be prevented from entry, and the alleged restrictions that ensued, including upon their right to marriage and choice of spouse, to education as well as to medical care and to equal treatment before tribunals, are capable of falling within the scope of CERD ratione materiae. The Court considers that, while the Parties differ on the question whether the expression "national . . origin" mentioned in Article 1, paragraph 1, of CERD, encompasses discrimination based on the "present nationality" of the individual, the Court need not decide at this stage of the proceedings, in view of what is stated above, which of these diverging interpretations of the Convention is the correct one.

28. The Court finds that the above-mentioned elements are sufficient at this stage to establish the existence of a dispute between the Parties concerning the interpretation or application of CERD.

\section{Procedural preconditions}

29. The Court recalls that it has previously indicated that the terms of Article 22 of CERD establish procedural preconditions to be met before the seisin of the Court (see Application of the International Convention on the Elimination of All Forms of Racial Discrimination (Georgia v. Russian Federation), Preliminary Objections, Judgment, I.C.J. Reports 2011 (I), p. 128, para. 141). Under Article 22 of CERD, the dispute referred to the Court must be a dispute "not settled by negotiation or by the procedures expressly provided for in this Convention". In addition, Article 22 states that the dispute may be referred to the Court at the request of any of the parties to the 
dispute only if the parties have not agreed to another mode of settlement. The Court notes that neither Party contends that they have agreed to another mode of settlement.

30. Concerning the first precondition under Article 22, Qatar asserts that it made "genuine attempts to negotiate with the UAE in order to bring an end to the dispute and to the human rights violations that continue to impose suffering on its people". It adds that it has repeatedly raised questions of specific human rights violations resulting from unlawful acts of discrimination by the UAE against Qataris, since June 2017. More specifically, the Applicant refers to declarations made by high-ranking State officials, in particular an address made on 25 February 2018 to the United Nations Human Rights Council by Qatar's Minister for Foreign Affairs. Qatar asserts moreover that its Minister of State for Foreign Affairs, by a letter dated 25 April 2018, expressly referred to violations of specific provisions of CERD through the UAE's actions of 5 June 2017, and called on the UAE "to enter into negotiations in order to resolve these violations and the effects thereof'. The Applicant indicates that, although the invitation asked for a reply within two weeks, the UAE never responded. The Applicant therefore considers that the UAE has either rebuffed or ignored Qatar's efforts to negotiate a peaceful resolution to the dispute and that the Parties have not consequently been able to settle their dispute, despite genuine attempts by Qatar to negotiate.

31. With regard to the second precondition included in Article 22 of CERD, namely the use of the procedures expressly provided for in the Convention, Qatar states that it deposited, on 8 March 2018, a communication with the CERD Committee under Article 11 of the Convention. It argues, however, that initiation or completion of that procedure is not a precondition to the Court's exercise of jurisdiction in the present case. It also points out that it does not rely on this communication for the purposes of showing prima facie jurisdiction.

32. The Applicant finally expresses the view that, in any event, the question whether the two preconditions included in Article 22 of CERD have a cumulative and successive character should not be decided by the Court at this stage.

33. In response to Qatar's arguments concerning the fulfilment of the preconditions included in Article 22 of CERD, the UAE first of all contends that they are cumulative and must be fulfilled successively before the seisin of the Court.

34. As far as the fulfilment of the first precondition is concerned, the UAE argues that, despite its allegations, Qatar has never made a "genuine attempt to negotiate" regarding the application of CERD. According to the UAE, the statements relied on by Qatar only relate very broadly to routine allegations of human rights violations and when, in passing, these documents mention CERD, the reference is not accompanied by any form of proposal to negotiate. It adds that none of these statements can be considered as an offer to negotiate with a view to settling the dispute alleged by Qatar under Article 22 of CERD. With regard to Qatar's letter dated 25 April 2018, which was received, according to the Respondent, on 1 May 2018, the UAE states that this document once again concerns alleged human rights violations in general, and makes no mention of Article 22 of CERD. The UAE asserts that this alleged offer took the form of an "ultimatum", and underlines that it was sent almost a year after the Ministry of Foreign Affairs of the UAE made a statement asking Qataris to leave the country within 14 days. The UAE explains that it neither accepted nor refused Qatar's alleged invitation. It affirms that it was informed only on 7 May 2018 that Qatar had addressed a communication to the CERD Committee. It also points out that Qatar submitted to the Court, on 11 June 2018, its Application instituting the proceedings in the present case and at the same time requested provisional measures without waiting for the outcome of the procedure before the CERD Committee. The UAE therefore concludes that, while it is true that the alleged dispute has not been settled by negotiation, "there has been no 'genuine attempt' to do so".

35. Regarding the second precondition included in Article 22 of CERD, namely the use of the procedures expressly provided for in the Convention, the UAE submits that Qatar must exhaust the procedure in the CERD Committee before seising the Court. In the alternative, the Respondent considers that the way in which Qatar has proceeded is incompatible with both the electa una via principle and the lis pendens exception, as the same claim has been submitted to two different bodies by the same applicant against the same respondent. 
36. Regarding the first precondition, namely the negotiations to which the compromissory clause refers, the Court observes that negotiations are distinct from mere protests or disputations and require a genuine attempt by one of the parties to engage in discussions with the other party, with a view to resolving the dispute. Where negotiations are attempted or have commenced, the precondition of negotiation is only met when the attempt to negotiate has been unsuccessful or where negotiations have failed, or become futile or deadlocked. In order to meet the precondition of negotiation contained in the compromissory clause of a treaty, "the subject-matter of the negotiations must relate to the subject-matter of the dispute which, in turn, must concern the substantive obligations contained in the treaty in question" (see Application of the International Convention on the Elimination of All Forms of Racial Discrimination (Georgia v. Russian Federation), Preliminary Objections, Judgment, I.C.J. Reports 2011 (I), p. 133, para. 161). At this stage of the proceedings, the Court first has to assess whether it appears that Qatar genuinely attempted to engage in negotiations with the UAE, with a view to resolving their dispute concerning the latter's compliance with its substantive obligations under CERD, and whether it appears that Qatar pursued these negotiations as far as possible.

37. The Court notes that it has not been challenged by the Parties that issues relating to the measures taken by the UAE in June 2017 have been raised by representatives of Qatar on several occasions in international fora, including at the United Nations, in the presence of representatives of the UAE. For example, during the 37th session of the United Nations Human Rights Council in February 2018, the Minister for Foreign Affairs of Qatar referred to "the violations of human rights caused by the unjust blockade and the unilateral coercive measures imposed on [his] country that have been confirmed by the . . report of the Office of the United Nations High Commissioner for Human Rights Technical Mission", while the UAE — along with Bahrain, Saudi Arabia and Egypt - issued a joint statement "in response to [the] remarks" made by the Minister for Foreign Affairs of Qatar.

38. The Court further notes that, in a letter dated 25 April 2018 and addressed to the Minister of State for Foreign Affairs of the UAE, the Minister of State for Foreign Affairs of Qatar referred to the alleged violations of CERD arising from the measures taken by the UAE beginning on 5 June 2017 and stated that "it [was] necessary to enter into negotiations in order to resolve these violations and the effects thereof within no more than two weeks". The Court considers that the letter contained an offer by Qatar to negotiate with the UAE with regard to the latter's compliance with its substantive obligations under CERD. In the light of the foregoing, and given the fact that the UAE did not respond to that formal invitation to negotiate, the Court is of the view that the issues raised in the present case had not been resolved by negotiations at the time of the filing of the Application.

39. The Court now turns to the second precondition contained in Article 22 of CERD, relating to "the procedures expressly provided for in the Convention". It is recalled that, according to Article 11 of the Convention, "[i]f a State Party considers that another State Party is not giving effect to the provisions of this Convention", the matter may be brought to the attention of the CERD Committee. The Court notes that Qatar deposited, on 8 March 2018, a communication with the CERD Committee under Article 11 of the Convention. It observes, however, that Qatar does not rely on this communication for the purposes of showing prima facie jurisdiction in the present case. Although the Parties disagree as to whether negotiations and recourse to the procedures referred to in Article 22 of CERD constitute alternative or cumulative preconditions to be fulfilled before the seisin of the Court, the Court is of the view that it need not make a pronouncement on the issue at this stage of the proceedings (see Application of the International Convention for the Suppression of the Financing of Terrorism and of the International Convention on the Elimination of All Forms of Racial Discrimination (Ukraine v. Russian Federation), Provisional Measures, Order of 19 April 2017, I.C.J. Reports 2017, pp. 125-126, para. 60). Nor does it consider it necessary, for the present purposes, to decide whether any electa una via principle or lis pendens exception are applicable in the present situation.

40. The Court thus finds, in view of all the foregoing, that the procedural preconditions under Article 22 of CERD for its seisin appear, at this stage, to have been complied with. 


\section{CONCLUSION AS TO PRIMA FACIE JURISDICTION}

41. In light of the foregoing, the Court concludes that, prima facie, it has jurisdiction pursuant to Article 22 of CERD to deal with the case to the extent that the dispute between the Parties relates to the "interpretation or application" of the said Convention.

42. The Court notes that the UAE has contended that Qatar had to prove that its citizens had exhausted local remedies before it seised the Court and that Qatar has denied that the exhaustion of local remedies is a precondition for the seisin of the Court in the present case. The Court observes that, in the current proceedings, Qatar asserts its rights on the basis of alleged violations of CERD by the UAE. The Court further notes that the UAE did not indicate any effective local remedies that were available to the Qataris that have not been exhausted. The Court is of the view that, at this stage of the proceedings relating to a request for the indication of provisional measures, the issue of exhaustion of local remedies need not be addressed by the Court.

\section{THE RIGHTS WHOSE PROTECTION IS SOUGHT AND THE MEASURES REQUESTED}

43. The power of the Court to indicate provisional measures under Article 41 of the Statute has as its object the preservation of the respective rights of the parties in a case, pending its decision on the merits thereof. It follows that the Court must be concerned to preserve by such measures the rights which may subsequently be adjudged by it to belong to either party. Therefore, the Court may exercise this power only if it is satisfied that the rights asserted by the party requesting such measures are at least plausible (see, for example, Application of the International Convention for the Suppression of the Financing of Terrorism and of the International Convention on the Elimination of All Forms of Racial Discrimination (Ukraine v. Russian Federation), Provisional Measures, Order of 19 April 2017, I.C.J. Reports 2017, p. 126, para. 63).

44. At this stage of the proceedings, the Court, however, is not called upon to determine definitively whether the rights which Qatar wishes to see protected exist; it need only decide whether the rights claimed by Qatar on the merits, and for which it is seeking protection, are plausible. Moreover, a link must exist between the rights whose protection is sought and the provisional measures being requested (ibid., para. 64).

45. In its Application, Qatar asserts rights under Articles 2, 4, 5, 6 and 7 of CERD. In its Request for the indication of provisional measures, in order to identify the rights which it seeks to protect pending a decision on the merits, Qatar refers to Articles 2, 4, 5 and 6 of the Convention and, in the course of the oral proceedings on its Request, it also referred to Article 7 of the Convention. In those hearings, Qatar asserted that the UAE was violating the Convention's prohibition on collective expulsion, interfering with Qataris' basic human rights under Articles 2 and 5, inciting and failing to condemn racial hatred and prejudice under Articles 4 and 7, and denying effective protection and remedies against acts of racial discrimination under Article 6.

46. Qatar states that the alleged rights are plausible in so far as they are "grounded in a possible interpretation" of the treaty invoked. For Qatar, the definition of racial discrimination under Article 1, paragraph 1, of the Convention "is a question of plausibility of the rights asserted". Qatar submits that "the measures imposed by the UAE on 5 June 2017 and thereafter make clear their purpose: racial discrimination based on national origin". In the second round of oral observations, Qatar added that "the Convention cannot be read to exclude discriminatory conduct based on Qatari national origin or nationality". Qatar argues that its "claims that the UAE is singling out Qataris and only Qataris en masse for discriminatory treatment raise plausible rights supporting an indication of provisional measures".

47. With regard to evidence adduced to demonstrate the plausibility of the rights it claims, Qatar refers in particular to the December 2017 report of the Technical Mission despatched by the Office of the United Nations 
High Commissioner for Human Rights (hereinafter "OHCHR") which concluded that the measures put in place by the UAE had "a potentially durable effect on the enjoyment of the human rights and fundamental freedoms of those affected". Qatar argues, in conclusion, that the rights it claims clearly fulfil the condition of plausibility.

48. The UAE, for its part, contends that in making its claim, and in attempting to provide a basis for the measures requested, Qatar seeks to give an unacceptably broad interpretation to a number of the obligations enumerated in Article 5 of the Convention, and that, as a consequence, the rights on which it seeks to rely are not plausible. It submits that the definition of "racial discrimination" in Article 1, paragraph 1, of CERD does not apply to differences of treatment on the basis of "present nationality" (see paragraph 24 above).

49. The UAE also argues that the lack of evidence supporting Qatar's claims calls into question the plausibility of the rights asserted by Qatar. In particular, it maintains that the report of the Technical Mission of the OHCHR relates to events which occurred over seven months earlier and that its relevance to the circumstances prevailing at this moment is highly questionable.

50. The Court notes that CERD imposes a number of obligations on States parties with regard to the elimination of racial discrimination in all its forms and manifestations. Article 1 of CERD defines racial discrimination in the following terms:

"any distinction, exclusion, restriction or preference based on race, colour, descent, or national or ethnic origin which has the purpose or effect of nullifying or impairing the recognition, enjoyment or exercise, on an equal footing, of human rights and fundamental freedoms in the political, economic, social, cultural or any other field of public life".

Articles 2, 4, 5, 6 and 7 of the Convention, invoked by Qatar, read as follows:

\section{Article 2}

1. States Parties condemn racial discrimination and undertake to pursue by all appropriate means and without delay a policy of eliminating racial discrimination in all its forms and promoting understanding among all races, and, to this end:

(a) Each State Party undertakes to engage in no act or practice of racial discrimination against persons, groups of persons or institutions and to ensure that all public authorities and public institutions, national and local, shall act in conformity with this obligation;

(b) Each State Party undertakes not to sponsor, defend or support racial discrimination by any persons or organizations;

(c) Each State Party shall take effective measures to review governmental, national and local policies, and to amend, rescind or nullify any laws and regulations which have the effect of creating or perpetuating racial discrimination wherever it exists;

(d) Each State Party shall prohibit and bring to an end, by all appropriate means, including legislation as required by circumstances, racial discrimination by any persons, group or organization;

(e) Each State Party undertakes to encourage, where appropriate, integrationist multi-racial organizations and movements and other means of eliminating barriers between races, and to discourage anything which tends to strengthen racial division.

2. States Parties shall, when the circumstances so warrant, take, in the social, economic, cultural and other fields, special and concrete measures to ensure the adequate development and protection of certain racial groups or individuals belonging to them, for the purpose of guaranteeing them the full and equal enjoyment of human rights 
and fundamental freedoms. These measures shall in no case entail as a consequence the maintenance of unequal or separate rights for different racial groups after the objectives for which they were taken have been achieved.

\section{Article 4}

States Parties condemn all propaganda and all organizations which are based on ideas or theories of superiority of one race or group of persons of one colour or ethnic origin, or which attempt to justify or promote racial hatred and discrimination in any form, and undertake to adopt immediate and positive measures designed to eradicate all incitement to, or acts of, such discrimination and, to this end, with due regard to the principles embodied in the Universal Declaration of Human Rights and the rights expressly set forth in article 5 of this Convention, inter alia:

(a) Shall declare an offence punishable by law all dissemination of ideas based on racial superiority or hatred, incitement to racial discrimination, as well as all acts of violence or incitement to such acts against any race or group of persons of another colour or ethnic origin, and also the provision of any assistance to racist activities, including the financing thereof;

(b) Shall declare illegal and prohibit organizations, and also organized and all other propaganda activities, which promote and incite racial discrimination, and shall recognize participation in such organizations or activities as an offence punishable by law;

(c) Shall not permit public authorities or public institutions, national or local, to promote or incite racial discrimination.

\section{Article 5}

In compliance with the fundamental obligations laid down in article 2 of this Convention, States Parties undertake to prohibit and to eliminate racial discrimination in all its forms and to guarantee the right of everyone, without distinction as to race, colour, or national or ethnic origin, to equality before the law, notably in the enjoyment of the following rights:

(a) The right to equal treatment before the tribunals and all other organs administering justice;

(b) The right to security of person and protection by the State against violence or bodily harm, whether inflicted by government officials or by any individual group or institution;

(c) Political rights, in particular the right to participate in elections - to vote and to stand for election on the basis of universal and equal suffrage, to take part in the Government as well as in the conduct of public affairs at any level and to have equal access to public service;

(d) Other civil rights, in particular:

(i) The right to freedom of movement and residence within the border of the State;

(ii) The right to leave any country, including one's own, and to return to one's country;

(iii) The right to nationality;

(iv) The right to marriage and choice of spouse;

(v) The right to own property alone as well as in association with others;

(vi) The right to inherit;

(vii) The right to freedom of thought, conscience and religion;

(viii) The right to freedom of opinion and expression;

(ix) The right to freedom of peaceful assembly and association; 
(e) Economic, social and cultural rights, in particular:

(i) The rights to work, to free choice of employment, to just and favourable conditions of work, to protection against unemployment, to equal pay for equal work, to just and favourable remuneration;

(ii) The right to form and join trade unions;

(iii) The right to housing;

(iv) The right to public health, medical care, social security and social services;

(v) The right to education and training;

(vi) The right to equal participation in cultural activities;

(f) The right of access to any place or service intended for use by the general public, such as transport, hotels, restaurants, cafés, theatres and parks.

\section{Article 6}

States Parties shall assure to everyone within their jurisdiction effective protection and remedies, through the competent national tribunals and other State institutions, against any acts of racial discrimination which violate his human rights and fundamental freedoms contrary to this Convention, as well as the right to seek from such tribunals just and adequate reparation or satisfaction for any damage suffered as a result of such discrimination.

\section{Article 7}

States Parties undertake to adopt immediate and effective measures, particularly in the fields of teaching, education, culture and information, with a view to combating prejudices which lead to racial discrimination and to promoting understanding, tolerance and friendship among nations and racial or ethnical groups, as well as to propagating the purposes and principles of the Charter of the United Nations, the Universal Declaration of Human Rights, the United Nations Declaration on the Elimination of All Forms of Racial Discrimination, and this Convention."

51. The Court recalls, as it did in past cases in which CERD was at issue, that there is a correlation between respect for individual rights, the obligations of States parties under CERD and the right of States parties to seek compliance therewith (see Application of the International Convention for the Suppression of the Financing of Terrorism and of the International Convention on the Elimination of All Forms of Racial Discrimination (Ukraine v. Russian Federation), Provisional Measures, Order of 19 April 2017, I.C.J. Reports 2017, p. 135, para. 81).

52. The Court notes that Articles 2, 4, 5, 6 and 7 of CERD are intended to protect individuals from racial discrimination. Consequently, in the context of a request for the indication of provisional measures, a State party to CERD may avail itself of the rights under the above-mentioned Articles only if the acts complained of appear to constitute acts of racial discrimination as defined in Article 1 of the Convention.

53. In this regard, the Court recalls its conclusion that it need not decide at this stage of the proceedings between the divergent views of the Parties on whether the expression "national . . origin" in Article 1, paragraph 1, of CERD encompasses discrimination based on "present nationality" (see paragraph 27 above).

54. In the present case, the Court notes, on the basis of the evidence presented to it by the Parties, that the measures adopted by the UAE on 5 June 2017 appear to have targeted only Qataris and not other non-citizens residing in the UAE. Furthermore, the measures were directed to all Qataris residing in the UAE, regardless of individual circumstances. Therefore, it appears that some of the acts of which Qatar complains may constitute acts of racial discrimination as defined by the Convention. Consequently, the Court finds that at least some of the rights asserted by Qatar under Article 5 of CERD are plausible. This is the case, for example, with respect to the alleged racial discrimination in the enjoyment of rights such as the right to marriage and to choice of spouse, the right to education, as well as freedom of movement, and access to justice. 
55. The Court now turns to the issue of the link between the rights claimed and the provisional measures requested.

56. Qatar contends that there is clearly a link between all the measures requested and the various rights arising out of CERD whose protection it seeks, including the general prohibition of racial discrimination, the prohibition of hate speech, and the enjoyment of civil and political rights, as well as economic, social and cultural rights referred to in Article 5 of the Convention.

57. The UAE, for its part, contends that the requisite link between the rights relied upon and the measures sought is not present. In particular, it argues that the principal aim of the provisional measures being requested is the overturning of the alleged limitations on the entry of Qatari nationals to the UAE; however, according to the UAE, the measures sought are as such insufficiently linked to the rights which Qatar asserts are at issue.

58. The Court has already found (see paragraph 54 above) that at least some of the rights asserted by Qatar under Article 5 of CERD are plausible. It recalls that Article 5 prohibits discrimination in the enjoyment of a variety of civil and political rights and economic, social and cultural rights. The Court considers that the measures requested by Qatar (see paragraph 11 above) are aimed not only at ending any collective expulsion of Qataris from the territory of the UAE, but also at protecting other specific rights contained in Article 5.

59. The Court concludes, therefore, that a link exists between the rights whose protection is being sought and the provisional measures being requested by Qatar.

\section{RISK OF IRREPARABLE PREJUDICE AND URGENCY}

60. The Court, pursuant to Article 41 of its Statute, has the power to indicate provisional measures when irreparable prejudice could be caused to rights which are the subject of judicial proceedings (see, for example, Jadhav (India v. Pakistan), Provisional Measures, Order of 18 May 2017, I.C.J. Reports 2017, p. 243, para. 49; Application of the International Convention for the Suppression of the Financing of Terrorism and of the International Convention on the Elimination of All Forms of Racial Discrimination (Ukraine v. Russian Federation), Provisional Measures, Order of 19 April 2017, I.C.J. Reports 2017, p. 136, para. 88).

61. However, the power of the Court to indicate provisional measures will be exercised only if there is urgency, in the sense that there is a real and imminent risk that irreparable prejudice will be caused to the rights in dispute before the Court gives its final decision (Jadhav (India v. Pakistan), Provisional Measures, Order of 18 May 2017, I.C.J. Reports 2017, p. 243, para. 50; Application of the International Convention for the Suppression of the Financing of Terrorism and of the International Convention on the Elimination of All Forms of Racial Discrimination (Ukraine v. Russian Federation), Provisional Measures, Order of 19 April 2017, I.C.J. Reports 2017, p. 136, para. 89). The condition of urgency is met when the acts susceptible of causing irreparable prejudice can "occur at any moment" before the Court rules on the merits (Immunities and Criminal Proceedings (Equatorial Guinea v. France), Provisional Measures, Order of 7 December 2016, I.C.J. Reports 2016 (II), p. 1169, para. 90). The Court must therefore consider whether such a risk exists at this stage of the proceedings.

62. The Court is not called upon, for the purposes of its decision on the request for the indication of provisional measures, to establish the existence of breaches of CERD, but to determine whether the circumstances require the indication of provisional measures for the protection of rights under this instrument. It cannot at this stage make definitive findings of fact, and the right of each Party to submit arguments in respect of the merits remains unaffected by the Court's decision on the request for the indication of provisional measures.

63. Qatar submits that irreparable prejudice is the natural consequence of violations of the rights before the Court in this case and that no decision of the Court on the merits - whenever it is rendered - could "wipe out" all of this damage and "restore" the status quo ante. Qatar is of the view that, in the present case, the Court does not need to 
determine whether there is a risk of irreparable prejudice to those rights, since the evidence shows that this type of prejudice exists today and continues to be manifest, as a result of the UAE's refusal to comply with CERD. Qatar thus emphasizes the continuous nature of the violations of the fundamental rights alleged, namely the rights to movement and residence, family reunification, education, work, freedom of opinion and expression, health, freedom of religious practice, private property and the right to access courts in the UAE to protect Qatari property and assets or to challenge any discriminatory measures. Qatar stresses that the "durable consequences" of the continuous violation of the right to movement and residence on the right to work and to access property, as well as on the right to family reunification, was acknowledged in the report of the Technical Mission despatched by the OHCHR and, therefore, "cannot be questioned". Citing a report of Amnesty International dated 5 June 2018, Qatar asserts that, a year on, the situation has not improved and that residents of the region are still left facing uncertain futures. Qatar concludes that, since the damage is present and ongoing, the condition of imminence is also plainly fulfilled.

64. Qatar claims that the UAE has resisted all requests to terminate the discriminatory measures. It refers in particular to the issuance by the UAE of thirteen demands on 23 June 2017, supplemented by six demands on 5 July 2017, requesting, inter alia, that Qatar align itself with the other Gulf and Arab countries militarily, politically, socially, and economically, as a precondition for the lifting of the discriminatory measures. Qatar submits that, in doing so, the UAE has aggravated the dispute. Qatar contends that, in light of the UAE's refusal to suspend or withdraw its illegal acts, the people of Qatar could see an indefinite violation of their rights and would suffer damage and distress as a result. Accordingly, it considers that provisional measures are "urgently required to compel the UAE to abide by its international obligations under the CERD”.

65. The UAE denies that there exists a risk of irreparable prejudice to the rights of the Applicant under CERD. Challenging the reliance and independence of the evidence submitted to the Court by Qatar, it asserts that Qataris continue to enjoy the full rights granted by law to all residents of or visitors to the UAE. Although the UAE does not deny that it has severed relations with Qatar due to national security concerns, in particular its alleged support for terrorism and extremism, it asserts that the statement of 5 June 2017, whereby its Ministry of Foreign Affairs announced that Qataris were to leave the UAE within 14 days and that they would be prevented from entry, was carefully measured to have the least possible impact on the people of Qatar. The UAE asserts that there were in fact no legal steps taken by its Government to deport Qataris who remained after the 14-day period; restrictions were only imposed on Qataris wishing to enter the UAE, who were required to seek prior permission, which was almost always granted. The UAE adds that measures have been taken to deal with the problem of separation of families that include Qataris. Thus, a presidential directive, issued on 6 June 2017, instructed the authorities to take into account the humanitarian circumstances of UAE-Qatari mixed families, and a special telephone line was established to deal with such cases and to ensure that appropriate action was taken. The UAE argues that, even if the Court were to find that there is a risk of prejudice caused to the rights alleged by Qatar as a result of the actions of the UAE, the prejudice would not be irreparable.

66. The UAE further asserts that the situation is not urgent as alleged by Qatar. In addition to referring to the remedial measures already taken, as described in paragraph 65 above, it observes that the Request for provisional measures was filed by Qatar on 11 June 2018, i.e. more than a year after the Ministry of Foreign Affairs of the UAE made a statement asking Qatari nationals to leave the country within 14 days.

67. The Court considers that certain rights in question in these proceedings - in particular, several of the rights stipulated in Article 5, paragraphs $(a),(d)$ and $(e)$, of CERD - are of such a nature that prejudice to them is capable of causing irreparable harm (see Application of the International Convention for the Suppression of the Financing of Terrorism and of the International Convention on the Elimination of All Forms of Racial Discrimination (Ukraine v. Russian Federation), Provisional Measures, Order of 19 April 2017, I.C.J. Reports 2017, p. 138, para. 96). On the basis of the evidence presented to it by the Parties, the Court is of the opinion that the situation of Qataris residing in the UAE prior to 5 June 2017 appears to remain vulnerable with regard to their rights under Article 5 of the Convention. 
68. In this regard, the Court observes that, following the statement of 5 June 2017, whereby the Ministry of Foreign Affairs of the UAE announced that Qataris were to leave the territory within 14 days and that they would be prevented from entry, many Qataris residing in the UAE at that time appeared to have been forced to leave their place of residence without the possibility of return. The Court notes that a number of consequences apparently resulted from this situation and that the impact on those affected seem to persist to this date: UAE-Qatari mixed families have been separated; Qatari students have been deprived of the opportunity to complete their education in the UAE and to continue their studies elsewhere since UAE universities have refused to provide them with their educational records; and Qataris have been denied equal access to tribunals and other judicial organs in the UAE.

69. As the Court has already observed, individuals forced to leave their own place of residence without the possibility of return could, depending on the circumstances, be subject to a serious risk of irreparable prejudice (Application of the International Convention on the Elimination of All Forms of Racial Discrimination (Georgia v. Russian Federation), Provisional Measures, Order of 15 October 2008, I.C.J. Reports 2008, p. 396, para. 142). The Court is of the view that a prejudice can be considered as irreparable when individuals are subject to temporary or potentially ongoing separation from their families and suffer from psychological distress; when students are prevented from taking their exams due to enforced absence or from pursuing their studies due to a refusal by academic institutions to provide educational records; or when the persons concerned are impeded from being able to physically appear in any proceedings or to challenge any measure they find discriminatory.

70. The Court notes that the UAE stated, in response to a question posed by a Member of the Court at the end of the oral proceedings, that, following the statement of 5 June 2017 by its Ministry of Foreign Affairs, no administrative orders have been issued under the Immigration Law to expel Qataris. The Court nonetheless notes that it appears from the evidence before it that, as a result of this statement, Qataris felt obliged to leave the UAE resulting in the specific prejudices to their rights described above. Moreover, in view of the fact that the UAE has not taken any official steps to rescind the measures of 5 June 2017, the situation affecting the enjoyment of their above-mentioned rights in the UAE remains unchanged.

71. The Court thus finds that there is an imminent risk that the measures adopted by the UAE, as set out above, could lead to irreparable prejudice to the rights invoked by Qatar, as specified by the Court (see paragraph 54 above).

\section{CONCLUSION AND MEASURES TO BE ADOPTED}

72. The Court concludes from all of the above considerations that the conditions required by its Statute for it to indicate provisional measures are met. It is therefore necessary, pending its final decision, for the Court to indicate certain measures in order to protect the rights claimed by Qatar, as identified above (see paragraph 54 above).

73. The Court recalls that it has the power, under its Statute, when a request for provisional measures has been made, to indicate measures that are, in whole or in part, other than those requested. Article 75, paragraph 2, of the Rules of Court specifically refers to this power of the Court. The Court has already exercised this power on several occasions in the past (see, for example, Application of the International Convention for the Suppression of the Financing of Terrorism and of the International Convention on the Elimination of All Forms of Racial Discrimination (Ukraine v. Russian Federation), Provisional Measures, Order of 19 April 2017, I.C.J. Reports 2017, p. 139, para. 100).

74. In the present case, having considered the terms of the provisional measures requested by Qatar and the circumstances of the case, the Court finds that the measures to be indicated need not be identical to those requested.

75. Reminding the UAE of its duty to comply with its obligations under CERD, the Court considers that, with regard to the situation described above, the UAE must, pending the final decision in the case and in accordance with its obligations under CERD, ensure that families that include a Qatari, separated by the measures adopted by the UAE on 5 June 2017, are reunited, that Qatari students affected by those measures are given the opportunity to complete their education in the UAE or to obtain their educational records if they wish to continue their studies elsewhere, and that Qataris affected by those measures are allowed access to tribunals and other judicial organs of the UAE. 
76. The Court recalls that Qatar has requested it to indicate measures aimed at ensuring the non-aggravation of the dispute with the UAE. When it is indicating provisional measures for the purpose of preserving specific rights, the Court may also indicate provisional measures with a view to preventing the aggravation or extension of a dispute whenever it considers that the circumstances so require (see Application of the International Convention for the Suppression of the Financing of Terrorism and of the International Convention on the Elimination of All Forms of Racial Discrimination (Ukraine v. Russian Federation), Provisional Measures, Order of 19 April 2017, I.C.J. Reports 2017, p. 139, para. 103). In this case, having considered all the circumstances, in addition to the specific measures it has decided to take, the Court deems it necessary to indicate an additional measure directed to both Parties and aimed at ensuring the non-aggravation of their dispute.

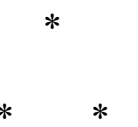

77. The Court reaffirms that its "orders on provisional measures under Article 41 [of the Statute] have binding effect" (LaGrand (Germany v. United States of America), Judgment, I.C.J. Reports 2001, p. 506, para. 109) and thus create international legal obligations for any party to whom the provisional measures are addressed.

$*$

78. The Court further reaffirms that the decision given in the present proceedings in no way prejudges the question of the jurisdiction of the Court to deal with the merits of the case or any questions relating to the admissibility of the Application or to the merits themselves. It leaves unaffected the right of the Governments of Qatar and the UAE to submit arguments in respect of those questions.

79. For these reasons,

\section{THE COURT,}

Indicates the following provisional measures:

(1) By eight votes to seven,

The United Arab Emirates must ensure that

(i) families that include a Qatari, separated by the measures adopted by the United Arab Emirates on 5 June 2017, are reunited;

(ii) Qatari students affected by the measures adopted by the United Arab Emirates on 5 June 2017 are given the opportunity to complete their education in the United Arab Emirates or to obtain their educational records if they wish to continue their studies elsewhere; and

(iii) Qataris affected by the measures adopted by the United Arab Emirates on 5 June 2017 are allowed access to tribunals and other judicial organs of the United Arab Emirates;

IN FAVOUR: President Yusuf; Vice-President Xue; Judges Abraham, Bennouna, Cançado Trindade, Sebutinde, Robinson; Judge ad hoc Daudet;

AGAINST: Judges Tomka, Gaja, Bhandari, Crawford, Gevorgian, Salam; Judge ad hoc Cot;

(2) By eleven votes to four, 
Both Parties shall refrain from any action which might aggravate or extend the dispute before the Court or make it more difficult to resolve.

IN FAVOUR: President Yusuf; Vice-President Xue; Judges Tomka, Abraham, Bennouna, Cançado Trindade, Gaja, Sebutinde, Bhandari, Robinson; Judge ad hoc Daudet;

AGAINST: Judges Crawford, Gevorgian, Salam; Judge ad hoc Cot.

Done in English and in French, the English text being authoritative, at the Peace Palace, The Hague, this twenty-third day of July, two thousand and eighteen, in three copies, one of which will be placed in the archives of the Court and the others transmitted to the Government of the State of Qatar and the Government of the United Arab Emirates, respectively.

(Signed) Abdulqawi Ahmed YUSUF, President.

(Signed) Philippe COUVREUR, Registrar.

Judges TOMKA, GAJA and GEVORGIAN append a joint declaration to the Order of the Court; Judge CANÇADO TRINDADE appends a separate opinion to the Order of the Court; Judges BHANDARI, CRAWFORD and SALAM append dissenting opinions to the Order of the Court; Judge ad hoc COT appends a dissenting opinion to the Order of the Court.

(Initialled) A.A.Y.

(Initialled) Ph.C. 


\section{JOINT DECLARATION OF JUDGES TOMKA, GAJA AND GEVORGIAN}

Dispute should prima facie fall within the scope of the treaty containing the compromissory clause - Factors to be taken into account for the purposes of the prohibition of racial discrimination - "National origin" not identical to "nationality" - Discrimination based on nationality does not prima facie fall within the scope of CERD.

We have not been able to support the Court's Order for the reasons explained below. Our vote, however, does not imply that we have no understanding for the humanitarian considerations underlying a call that the mixed QatariEmirati families remain united or, if they were separated, be able to reunite, that Qatari students be able to continue their studies in the United Arab Emirates (hereinafter "UAE") or elsewhere and that Qataris have access, in case of need, to tribunals and other judicial organs in the UAE. We do hope that the rights of these people are respected. However, we believe that certain legal requirements for the Court to indicate provisional measures are not met in the present case.

1. When assessing prima facie its jurisdiction and the plausibility of the rights invoked by the requesting Party in view of the adoption of provisional measures, the Court has to ascertain that prima facie the dispute falls within the scope of the treaty that contains the compromissory clause conferring jurisdiction on the Court and that the claimed rights are plausibly based on that treaty. Thus, for instance, in Immunities and Criminal Proceedings (Equatorial Guinea v. France) the Court found that "prima facie, a dispute capable of falling within the provisions of the Convention against Transnational Organized Crime and therefore concerning the interpretation or the application of Article 4 of that Convention d[id] not exist" (Provisional Measures, Order of 7 December 2016, I.C.J. Reports 2016 (II), p. 1160, para. 50). Similarly, in Application of the International Convention for the Suppression of the Financing of Terrorism and of the International Convention on the Elimination of All Forms of Racial Discrimination (Ukraine v. Russian Federation), the Court concluded that "the conditions required for the indication of provisional measures in respect of the rights alleged by Ukraine on the basis of the ICSFT are not met" (Provisional Measures, Order of 19 April 2017, I.C.J. Reports 2017, p. 132, para. 76).

2. In the present case, Qatar alleges certain violations by the UAE of obligations under the International Convention on the Elimination of All Forms of Racial Discrimination (hereinafter "CERD"), which contains in Article 22 a compromissory clause with respect to disputes concerning the interpretation or application of CERD.

3. The basis of the alleged discrimination in the treatment of individuals by the UAE of which Qatar has complained consists in the Qatari nationality of the persons concerned. However, CERD only applies to some specific factors of discrimination: "race, colour, descent, or national or ethnic origin". Nationality is not listed in Article 1, paragraph 1, among the bases of discrimination to which CERD applies.

4. When the Convention considers "national origin" as one of the prohibited bases for discrimination, it does not refer to nationality. In our view, the two terms are not identical and should not be understood as synonymous. The travaux préparatoires support this view and indicate that States sought to exclude distinction on the basis of nationality from the scope of CERD. In the discussions of the draft Convention in the Third Committee of the General Assembly, an amendment specifying that "the expression 'national origin' does not mean 'nationality' or 'citizenship" was withdrawn by their sponsors, but this was done only in favour of the final text of Article 1, which evidently was considered to make matters equally clear (United Nations, doc. A/6181, pp. 12-13). The omission of a reference to nationality may be easily explained. Should CERD be considered as covering also discrimination based on nationality, the Convention would be a far-reaching instrument, that contains a clause providing that, with regard to the wide array of civil rights that are protected under CERD, all foreigners must be treated by the host State in the same way as nationals of the State who enjoy the most favourable treatment.

5. The CERD Committee has taken the view - in particular, in paragraph 4 of its General Recommendation No. $\mathrm{XXX}$ on discrimination against non-citizens - that the Convention should be interpreted as covering also differences of treatment on the basis of nationality. However, the CERD Committee has not stated in as many words that nationality is equivalent to national origin. It has rather identified certain conditions for the prohibition of discrimination that are specific to nationality and immigration and do not apply when the bases of discrimination listed in Article 1, paragraph 1, are in question. It would be difficult to give weight to this view of the CERD Committee 
since it gives no reason for its interpretation that different treatment based on nationality constitutes racial discrimination under CERD, albeit only to a certain extent.

6. It is true that, when Article 1, paragraph 2, sets forth that CERD does not apply to differences of treatment between citizens and non-citizens, it does not exclude that the Convention applies to differences between a group of foreigners and another group of foreigners. However, even in that case, in order to be relevant under CERD, discrimination must rest on one of the bases listed in Article 1, paragraph 1. Differences of treatment of persons of a specific nationality may target persons who also have a certain ethnic origin and therefore would come under the purview of CERD, but this possibility has not been suggested by Qatar.

7. These remarks lead to the conclusion that the dispute of which the Court is seised does not fall prima facie within the scope of CERD and that the rights that are invoked under CERD are not plausible. This does not mean that the conduct of the UAE could not be viewed as inconsistent with other rules of international law, but in the present case the Court is called to examine only the claims put forward under CERD.

(Signed) Peter TOMKA.

(Signed) Giorgio GAJA.

(Signed) Kirill GEVORGIAN. 


\section{SEPARATE OPINION OF JUDGE CANÇADO TRINDADE}

Table of Contents

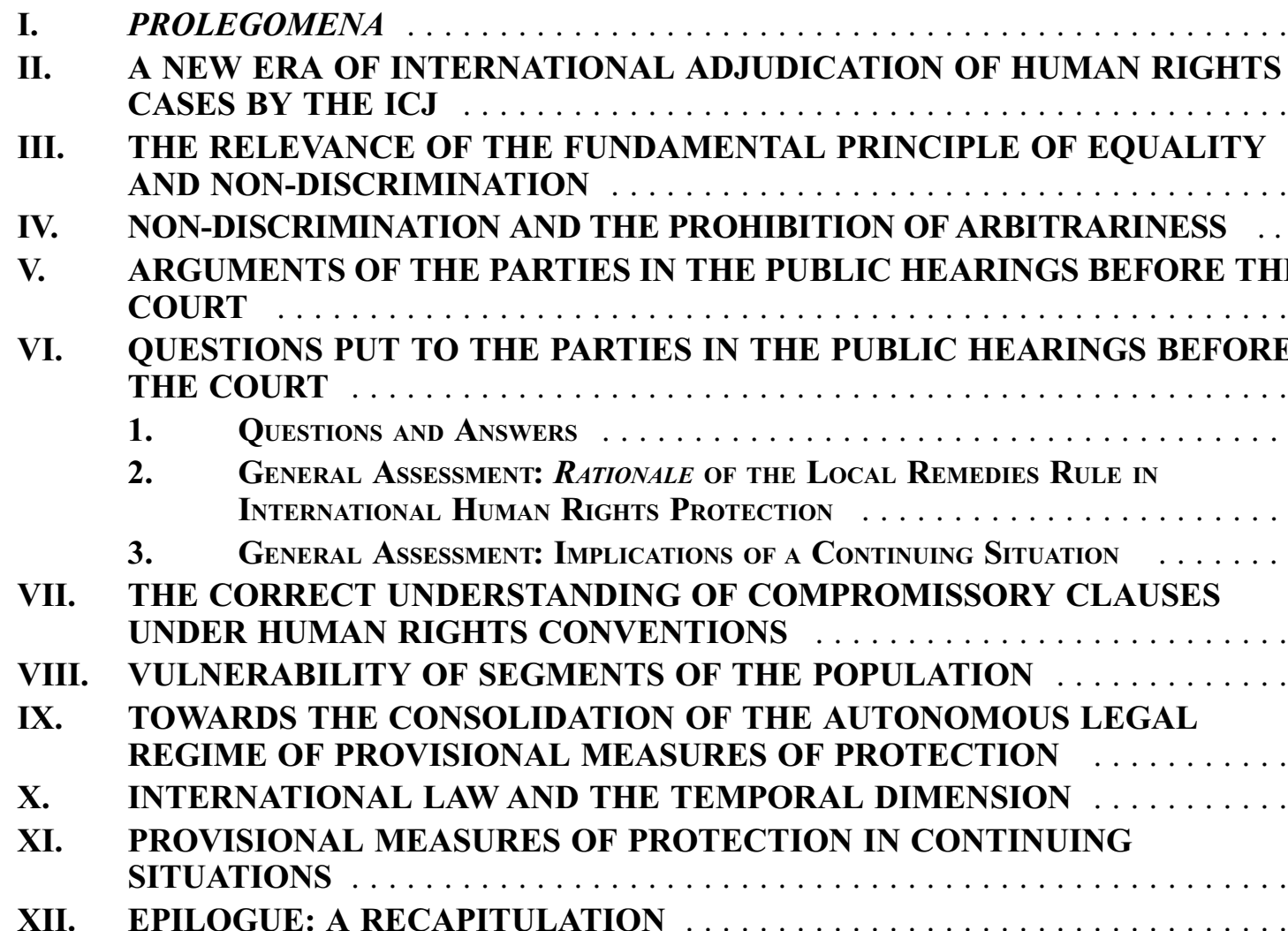

Paragraphs

996

997

998

1000

1001

1002

1002

1004

1005

1005

1006

1007

1008

1008

1010

\section{PROLEGOMENA.}

1. I have concurred, with my vote, for the adoption today, 23 July 2018, by the International Court of Justice (ICJ), of the present Order indicating Provisional Measures of Protection in the case of the International Convention on the Elimination of All Forms of Racial Discrimination [CERD] (Qatar versus United Arab Emirates - UAE). The ICJ has rightly ordered today, with my support, provisional measures of protection, under the CERD Convention. Additionally, as I attribute great importance to some related issues in the cas d'espèce, that in my perception underlie the present decision of the ICJ but are left out of the Court's reasoning, I feel obliged to leave on the records, in the present Separate Opinion, the identification of such issues and the foundations of my own personal position thereon.

2. I do so, under the merciless pressure of time, moved by a sense of duty in the exercise of the international judicial function, even more so as some of the lessons I extract from the matter forming the object of the present decision of the Court are not explicitly dealt with in the Court's reasoning in the present Order. This grows in importance in a case, like the present one (and two other cases before - cf. infra), lodged with the ICJ under a core human rights treaty like the CERD Convention.

3. This being so, I shall develop my reflections, initially, in the following sequence: a) a new era of international adjudication of human rights cases by the ICJ; b) the relevance of the fundamental principle of equality and nondiscrimination; and c) non-discrimination and the prohibition of arbitrariness. I shall then examine the arguments made by the contending Parties in the public hearings before the ICJ, and the written responses they presented to the questions that I have deemed it fit to put to them; following that, I shall provide my general assessment as to the rationale of the local remedies rule in international human rights protection, and as to implications of a continuing situation.

4. Following that, I shall develop my further reflections on the remaining points to consider, namely: a) the correct understanding of compromissory clauses under human rights Conventions; b) vulnerability of segments 
of the population; c) towards the consolidation of the autonomous legal regime of provisional measures of protection; d) international law and the temporal dimension; and e) provisional measures of protection in continuing situations. Last but not least, in an epilogue, I shall conclude with a recapitulation of the key points of the position I sustain in the present Separate Opinion.

5. To start with, may I recall that, in a relatively brief period of time (2011-2018), the cas d'espèce on Application of the International Convention on the Elimination of All Forms of Racial Discrimination (CERD Convention - Qatar versus UAE) is the third case lodged with the International Court of Justice (ICJ) under the United Nations CERD Convention: the present Order follows chronologically the Court's decisions in the cases of Georgia versus Russian Federation (preliminary objections, 2011) ${ }^{1}$ and of Ukraine versus Russian Federation (provisional measures of protection, 2017) ${ }^{2}$.

6. In addition to those three cases under the CERD Convention, there have been other cases brought before the ICJ, and decided by it, along the last eight years, concerning also other human rights treaties. May I recall, in this respect, the case on questions relating to the Obligation to Prosecute or Extradite (merits, 2012), under the U.N. Convention against Torture. Another example is provided by the case of A.S. Diallo (merits, 2010, and reparations, 2012), in respect of, inter alia, the U.N. Covenant on Civil and Political Rights (cf. infra).

\section{A NEW ERA OF INTERNATIONAL ADJUDICATION OF HUMAN RIGHTS CASES BY THE ICJ.}

7. To the ICJ's Judgment on the merits (of 30.11.2010) on the case of A.S. Diallo, opposing Guinea to D.R. Congo, I appended a Separate Opinion, wherein, inter alia, I deemed it fit to draw attention to the advent of a new era of international adjudication of human rights cases by the ICJ (paras. 232-245). In particular, - I singled out, - that was the first time in its history that "the World Court has expressly taken into account the contribution of the case-law of two international human rights tribunals, the European and the Inter-American Courts, to the perennial struggle of human beings against arbitrariness". In effect, - I added, - paragraph 65 of its Judgment referred to "the protection of the human person against arbitrary treatment, encompassing the prohibition of arbitrary expulsion" (para. 237). I then concluded that

"(...) It is indeed reassuring that the ICJ has disclosed a new vision of this particular issue, in so far as international human rights tribunals are concerned. This is particularly important at a time when States rely, in their submissions to this Court, on relevant provisions of human rights conventions, as both Guinea and the D.R. Congo have done in the present case, in their arguments centred on the U.N. Covenant on Civil and Political Rights and the African Charter on Human and Peoples' Rights (in addition to the relevant provision of the Vienna Convention on Consular Relations, in the framework of the international protection of human rights).

This is not the only example wherein this has occurred. On 29 May 2009, the ICJ delivered its Order (on provisional measures) in the case concerning Questions Relating to the Obligation to Prosecute or Extradite, wherein Belgium and Senegal presented their submissions concerning the interpretation and application of the relevant provisions of the 1984 U.N. Convention against Torture. And, very recently, a few days ago, in the public sittings before this Court of 13 to 17 September 2010, Georgia and the Russian Federation submitted their oral arguments in the case concerning the Application of the International Convention on the Elimination of All Forms of Racial Discrimination, another U.N. human rights treaty. It is reassuring that States begin to rely on human rights treaties before this Court, heralding a move towards an era of possible adjudication of human rights cases by the ICJ itself. The international juridical conscience has at last awakened to the fulfillment of this need.

The ICJ, in the exercise of its contentious as well as advisory functions in recent years, has referred either to relevant provisions of a human rights treaty such as the Covenant on Civil and Political Rights, or to the work of its supervisory organ, the Human Rights Committee. These antecedents are not to pass unnoticed, in acknowledging the turning-point which has just occurred in the present case of A.S. Diallo: the Court, in the Judgment being delivered today, 30 November 2010, has gone much further, beyond the United Nations system, in acknowledging the contribution 
of the jurisprudential construction of two other international tribunals, the Inter-American [IACtHR] and the European [ECtHR] Courts of Human Rights. It has also dwelt upon the contribution of an international human rights supervisory organ, the African Commission on Human and Peoples' Rights. The three regional human rights systems operate within the framework of the universality of human rights. (...)

By cultivating this dialogue, attentive to each other's work in pursuance of a common mission, contemporary international tribunals will provide avenues not only for States, but also for human beings, everywhere, and in respect of distinct domains of international law, to recover their faith in human justice. They will thus be enlarging and strengthening the aptitude of contemporary international law to resolve disputes occurred not only at inter-State level, but also at intra-State level. And they will thus be striving towards securing to States as well as to human beings what they are after: the realization of justice" (paras. 241-243 and 245).

8. In the light of the aforementioned, and bearing in mind all that has been happening here at the Grande Salle de Justice in the Peace Palace at The Hague in the last nine years, one is to acknowledge that we are already within the new era of international adjudication of human rights cases by the ICJ. The present case of Application of the CERD Convention (Qatar versus UAE) bears witness of that. Having pointed this out, I can now move to the next point to consider in this Separate Opinion, namely, the relevance of the fundamental principle of equality and non-discrimination.

\section{THE RELEVANCE OF THE FUNDAMENTAL PRINCIPLE OF EQUALITY AND NON-DISCRIMINATION.}

9. In the cas d'espèce, Qatar's Request for the Indication of Provisional Measures of Protection (of 11.06.2018) identifies the rights it seeks to protect against discriminatory measures that "violate the customary international law principle of non-discrimination as well as the specific obligations enumerated in CERD [Convention] Articles 2, 4, 5, 6,7 ' (p. 8, para. 12) ${ }^{4}$. The principle of equality and non-discrimination lies indeed in the foundations of the protected rights under the CERD Convention. This is a point which should have been attentively addressed by the contending parties in the course of the current proceedings ${ }^{5}$, which were largely consumed by diverting attention to points with no bearing at all on the consideration of provisional measures of protection under a human rights Convention.

10. This being so, I feel obliged to fill the gap, as I nourish the hope that this unfortunate diversion does not happen again in cases of the kind before the ICJ, where the applicable law is a human rights Convention, and not at all diplomatic protection rules. It is the principle of equality and non-discrimination which here calls for attention, there being no place for devising or imagining new "preconditions" for the consideration of provisional measures of protection under a human rights Convention; it makes no sense to intermingle at this stage the consideration of provisional measures with so-called "plausible admissibility" (cf. section VI, infra).

11. In focusing attention, thus, on the principle of equality and non-discrimination, it should not pass unnoticed, to start with, that the idea of human equality marked presence already in the origins of the law of nations (droit des gens), well before finding expression in the international instruments which conform its corpus juris gentium, as known in our times. The idea of human equality was underlying the original conception of the unity of human kind (present, for example, in the pioneering thinking of Francisco de Vitoria and Bartolomé de Las Casas in the XVIth century).

12. The fundamental principle of equality and non-discrimination is nowadays a basic pillar of the U.N. CERD Convention, and of the whole corpus juris of the International Law of Human Rights. The expression of such principle emanated from human conscience, and projected itself in the evolving law of nations from the XVIIth to the XXIst centuries. The principle of equality and non-discrimination has a long history, accompanying the historical formation and evolution of the law of nations itself.

13. By the mid-XXth century, the 1948 Universal Declaration of Human Rights proclaimed that "[a]11 human beings are born free and equal in dignity and rights. They are endowed with reason and conscience and should act towards one another in a spirit of brotherhood" (Article 1). It added that "[a]ll are equal before the law and 
are entitled without any discrimination to equal protection of the law. All are entitled to equal protection against any discrimination in violation of this Declaration and against any incitement to such discrimination" (Article 7).

14. And the 1945 Charter of the United Nations began by asserting the determination of "the peoples of the United Nations" to "reaffirm faith in fundamental human rights, in the dignity and worth of the human person, in the equal rights of men and women and of nations large and small" (second preambular paragraph). Nowadays, the fundamental principle of equality and non-discrimination lies also in the foundations of the Law of the United Nations itself.

15. The gradual consolidation of the mechanisms of international protection of human rights, moreover, has much contributed to a growing awareness of the importance of the prevalence of the basic principle of equality and non-discrimination. Certain expressions were to emerge (e.g., "equality before the law" and "equal protection of the law"), on the basis of human values, and associated to the corresponding obligations of States Parties to human rights treaties.

16. Supervisory organs of such treaties have been giving their constant contribution - of growing importance - to the prohibition of the discrimination de facto or de jure, in their faithful exercise of their functions of protection of the human person ${ }^{6}$. The obligation of non-discrimination as related to the substantive rights protected under those treaties draws attention to the positive obligations of the States Parties to secure the protection of the human beings under their jurisdiction against the discrimination in all ambits of human relations ${ }^{7}$.

17. For its part, the Committee on the Elimination of Racial Discrimination, for example, has in this respect issued General Recommendations orienting its own interpretation of the relevant provisions of the CERD Convention. Among them, there are those which have an incidence in the consideration of the present case of Application of the CERD Convention (Qatar versus UAE), namely: General Recommendation n. 30 (of 19.08.2004), on discrimination against non-citizens; General Recommendation n. 35 (of 26.09.2013), on combatting racist hate speech; General Recommendation n. 25 (of 20.03.2000), on gender-related dimensions of racial discrimination; General Recommendation n. 22 (of 23.08.1996), on Article 5 of the CERD Convention in relation to refugees and displaced persons.

18. The advances in respect of the basic principle of equality and non-discrimination at normative and jurisprudential levels ${ }^{8}$, have not, however, been accompanied by the international legal doctrine, which so far has not dedicated sufficient attention to that fundamental principle; it stands far from guarding proportion to its importance both in theory and practice of Law. This is one of the rare examples of international case-law preceding international legal doctrine, and requiring from it due and greater attention.

19. A significant jurisprudential advance is found in the ground-breaking Advisory Opinion n. 18 (of 17.09.2003) of the IACtHR, on the Juridical Condition and Rights of Undocumented Migrants, upholding the view that the fundamental principle of equality and non-discrimination had entered the realm of jus cogens, thus enlarging its material content (paras. 97-101 and 110-111) ${ }^{9}$. In the IACtHR's understanding, States cannot discriminate, nor tolerate discriminatory situations to the detriment of those persons; they had a duty to guarantee them the due process of law, irrespective of their migratory status. States can no longer subordinate or condition the observance of the principle of equality before the law and non-discrimination to the objectives of their migratory or other policies.

20. For my part, I focused on this significant jurisprudential advance in my Concurring Opinion appended to the aforementioned Advisory Opinion n. 18 of the IACtHR, wherein I stressed, in support of the Court's position, the relevance of the basic principle of equality and non-discrimination, enlarging the material content of jus cogens, and permeating, - together with other general principles of law, - the whole juridical order itself, conforming its substratum (paras. 44-46, 52-58, 65 and 72) ${ }^{10}$. Without such principles, there is ultimately no legal order at all. I developed my whole reasoning in the line of jusnaturalist thinking, - which marked the origins and historical evolution of the law of nations (droit des gens), - in the framework of the civitas maxima gentium and of the universality of the human kind.

21. The path was then paved for jurisprudential developments also in the international adjudication of contentious cases pertaining to the basic principle of equality and non-discrimination ${ }^{11}$. In effect, this fundamental principle has been addressed - in Judgments on contentious cases as well as in Advisory Opinions - in face of social 
marginalization (IACtHR, cases of Servellón-Garcia and Others, 2006, and of Indigenous Community Sawhoyamaxa, 2006); of prohibition of arbitrariness (ICJ, case of A.S. Diallo, merits, 2010, and reparations, 2012; Advisory Opinion on the Declaration of Independence of Kosovo, 2010; and case concerning the CERD Convention, 2011), as well as in face of procedural equality (IACtHR, case Loayza Tamayo, 1997; and ICJ, Advisory Opinion on Judgment of the ILO Administrative Tribunal on a Complaint against IFAD, 2012).

\section{NON-DISCRIMINATION AND THE PROHIBITION OF ARBITRARINESS.}

22. The protection being sought before the ICJ in the cas d'espèce, under the CERD Convention, is furthermore against arbitrary measures, against arbitrariness. Brief references were made to this in the course of the present oral pleadings before the $\mathrm{ICJ}^{12}$. This point has not escaped the attention of other international tribunals, under other human rights Conventions: for example, inter alia, in its Judgment (merits, of 03.07.2014) on the case of Georgia versus Russia, the European Court of Human Rights (ECtHR) singled out the duty under the European Convention on Human Rights (ECHR) "to protect the individual from arbitrariness", and found that the arrests and detentions that preceded "collective" expulsions (of nationals of the applicant State) amounted to "an administrative practice" in breach of Article 5(1) and (4) of the ECHR (paras. 182 and 186-188).

23. Subsequently, in its Judgment (merits, of 23.08.2016) on the case of J.K. and Others versus Sweden, concerning expulsion of non-citizens (the applicants being Iraqi nationals), the ECtHR held that, if deported, they would face a risk of being subjected to treatment in breach of Article 3 of the ECHR (para. 123) in the destination country. In effect, non-discrimination and the prohibition of arbitrariness are a point which cannot be overlooked, also in a wider framework, in time and space. After all, in the relations between human beings and public power, arbitrariness is an issue which has marked presence everywhere along the history of humankind. It has been a source of concern along the centuries. This is why the tragedies written and performed in ancient Greece remain so contemporary in our days, after so many centuries.

24. Suffice it here to recall, e.g., in Sophocles's Antigone (441 b.C.), the arbitrariness of the ruler Creon's decree prohibiting Antigone to bury the corpse of one of her deceased brothers (Polynices), and her determination nevertheless to do so in pursuance of justice; or else further to recall, some years later, e.g., in Euripides's Suppliant Women (424-419 b.C.), the arbitrariness that led to the grief and lamentation of the women whose deceased children had been separated from them, and their corpses then needed to be buried.

25. Sophocles's Antigone, in particular, has been rewritten, in successive centuries, by several other authors, bearing in mind their respective contemporary manifestations of arbitrariness. Although the ancient Greeks had eyes mainly for justice rather than law (and only later on, Romans of the ancient Empire began to distinguish between law and justice), there are those who seek to associate the tragedy of Sophocles with the seeds or origins of the distinction between natural law and positive law.

26. In any case, arbitrariness, as history shows, is unfortunately part of human nature, and the discrimination that ensues therefrom is both de facto and de jure. If we look at the world nowadays, marked by a serious crisis of values, we can see, in all continents, the inhumane split of families in frontiers, in particular those of migrants or noncitizens. Positive law alone cannot solve the problems created at times by itself, to the detriment of human beings in situations of vulnerability (cf. infra). Law and justice go together, they are indissociable, in the line of the more lucid jusnaturalist thinking.

27. It is important to keep those ancient Greek tragedies in mind also to face the so-called "globalization", - a misleading and false neologism en vogue in the XXIst century. Such neologism hides the marginalization and social exclusion of increasingly greater segments of the population (including migrants). Frontiers have been opened to capitals and goods, but are sadly being closed down to human beings (with split of families, and new walls, fences and detention centres, in distinct continents).

28. The material progress of some has been accompanied by the exploitation of many (including undocumented migrants). Some human beings (especially power-holders) have placed most fellow human beings in a scale of priority inferior to that attributed to capitals and goods. Nothing has been learned from sufferings of past generations; hence the need to remain attached to the goal of the realization of justice, bearing in mind that law and justice go 
indissociably together. The ICJ has a mission to keep on endeavouring to contribute to a humanized law of nations, in the dehumanized world of our days.

29. In my aforementioned Separate Opinion appended to the ICJ's Judgment on the case of A.S. Diallo (merits, of 30.11.2010), - concerning the arbitrary detentions followed by expulsion of a foreigner from his country of residence, - I devoted an entire section (VI) of it to "The Prohibition of Arbitrariness in the International Law of Human Rights" (paras. 107-142), wherein I examined the doctrinal development and the jurisprudential construction on the matter. I pondered, inter alia, that, as human rights treaties

"conform a Law of protection (a droit de protection), oriented towards the safeguard of the ostensibly weaker party, the victim, it is not at all surprising that the prohibition of arbitrariness (...) covers arrests and detentions, as well as other acts of the public power, such as expulsions" (para. 109).

30. Such has in fact been the understanding of international tribunals entrusted with the interpretation and application of human rights treaties, - like the ICJ in the present case of the Application of the CERD Convention (Qatar versus UAE). As I pointed out in that Separate Opinion in the case of A.S. Diallo, the case-law of international human rights tribunals is quite clear in this respect. No one can be deprived of liberty in an arbitrary way (cf. e.g., ECtHR, case of Amuur versus France, Judgment of 25.06.1996). No one can be detained or arrested, even when this is considered as "legal", when it is incompatible with the provisions of human rights treaties and carried out with arbitrariness (e.g., IACtHR, case of the "Street Children" - Villagrán Morales and Others versus Guatemala, merits, Judgment of 19.11.1999; cases of Bámaca Velásquez and of Maritza Urrutia versus Guatemala, Judgments of 25.11.2000 and of 27.11.2003, respectively).

31. The prohibition of arbitrariness, - I proceeded, - stands not only in respect of the right to personal liberty, but also in relation to all other rights protected under human rights treaties ${ }^{13}$, so as to secure the prevalence of the rule of law (la prééminence du droit). Epistemologically, this is the correct posture in this respect, given the universally acknowledged interrelatedness and indivisibility of all human rights. Arbitrariness amounts, in effect, to an abus de pouvoir on the part of the State agents. Accordingly, a domestic law or an administrative act, concerning migrants or non-citizens, cannot be applied when incompatible with the provisions of human rights treaties.

32. And in that Separate Opinion, I concluded, on the extent of the prohibition of arbitrariness, that

"Human nature being what it is, everyone needs to guard protection against arbitrariness on the part of State authorities. In a wider horizon, human beings need protection ultimately against themselves, in their relations with each other. There is hardly any need to require an express provision to the effect of prohibiting arbitrariness in respect of distinct rights, or else to require the insertion of the adjective 'arbitrary' in distinct provisions, in order to enable the exercise of protection against arbitrariness, in any circumstances, under human rights treaties. The letter together with the spirit of those provisions under human rights treaties, converge in pointing to the same direction: the absolute prohibition of arbitrariness, under the International Law of Human Rights as a whole. Underlying this whole matter is the imperative of access to justice lato sensu, the right to the Law (le droit au Droit, el derecho al Derecho), the right to the realization of justice in a democratic society" (para. 142).

\section{ARGUMENTS OF THE PARTIES IN THE PUBLIC HEARINGS BEFORE THE COURT.}

33. The prohibition of arbitrariness brings to the fore the issue of the vulnerability of those affected by discriminatory measures. Before examining this point (cf. section VII, infra), may I now turn to the arguments of the parties during the oral pleadings which have just taken place before the ICJ. In the course of the public hearings (first round) before the Court, the applicant State presented (on 27.06.2018) its own understanding of the factual context of the cas d'espèce within a temporal dimension.

34. Qatar argued that the "collective expulsion" of Qataris from the UAE as a discriminatory measure was ongoing, affecting continuously some of their rights under the CERD Convention (e.g., with the separation of 
families and loss of work); this was leading to the prolongation and indefinite duration ${ }^{14}$ of harm or damage, in the human tragedy ${ }^{15}$ of the numerous and vulnerable victims ${ }^{16}$. There was need for urgent regard to human suffering; the continuing vulnerability of segments of the population required urgently, in its view, provisional measures of protection.

35. In the following public hearings before the Court (still first round, on 28.06.2018), the respondent State did not address such issue of a continuing situation raised by Qatar; the UAE focused instead on other aspects, attempting to minimize and dismiss the request for provisional measures of protection ${ }^{17}$. It consumed much of the time of those public hearings raising the point (responded by the applicant State - infra), inter alia, of the rule of exhaustion of local remedies ${ }^{18}$.

36. In the second and last round of public hearings before the Court (on 29.06.2018) the local remedies rule continued to be addressed, this time by both the applicant State, in response to the argument of the respondent State, and by this latter once again ${ }^{19}$. The applicant State, furthermore, consistently reiterated its understanding of a continuing situation of ongoing alleged violations of human rights requiring "humanitarian considerations"20.

\section{QUESTIONS PUT TO THE PARTIES IN THE PUBLIC HEARINGS BEFORE THE COURT.}

\section{Questions and Answers.}

37. Those arguments advanced by the contending parties led me to address the following questions to both of them, at the end of the public hearings (on 29.06.2018):

"1. Does the local remedies rule have the same rationale in diplomatic protection and in international human rights protection? Does the effectiveness of local remedies have an incidence under the United Nations Convention on the Elimination of All Forms of Racial Discrimination and other human rights treaties?

2. Is it necessary to address the so-called plausibility of rights in face of a continuing situation allegedly affecting the rights protected under a human rights treaty like the United Nations Convention on the Elimination of All Forms of Racial Discrimination?

3. What are the implications or effects, if any, of the existence of a continuing situation allegedly affecting rights protected under a human rights Convention, for requests of provisional measures of protection?" ${ }^{21}$.

38. In the course of the following week, the contending parties provided the Court with their respective written answers (of 03.07.2018) to my questions, first, as to the rationale of the local remedies rule in diplomatic protection and in international human rights protection, and then, on the implications of a continuing situation. In respect of the first question, the applicant State, in its detailed written answer, first recalled that international human rights supervisory organs have stressed that the local remedies rule here requires "actual redress" for victims of human rights violations, determining the obligation of States Parties to human rights treaties to provide them with effective remedies $^{22}$. And it proceeded:

“This added element of 'actual redress' finally echoes the differences in the function of the local remedies rule in both systems, illustrated by Judge Cançado Trindade's seminal 1983 monograph on the subject ${ }^{23}$. In diplomatic protection, the local remedies rule ensures that disputes are not elevated onto the international plane before the authorities of the offending State have had an adequate opportunity to address them by their own means. It can thus be said that in diplomatic protection, the local remedies rule operates preemptively.

In international human rights protection, the focus of the rule is different. As explained above, under most major international human rights instruments, States have bound themselves to international obligations to respect and ensure human rights, including by subjecting those obligations to the scrutiny of national tribunals and other State institutions. By asking that such tribunals and other State institutions be resorted to before the violations are entrusted to the international machinery for their implementation, the rule thus operates protectively ${ }^{24,25}$. 
39. And the applicant State added that, under the CERD Convention and all other major human rights treaties, the local remedies rule only applies if remedies are effective, this being in accordance with general international law; the "principle of effectiveness" is here "fully applicable" 26 . In view of the foregoing, it submitted that "although there is a certain degree of overlap in the rationale of the local remedies rule in the fields of diplomatic protection and international human rights protection, in the latter, the rule is also underscored by an element of 'actual redress'. Such redress must, furthermore, be effective" ${ }^{\text {27 }}$.

40. For its part, the respondent State, in its brief written answer to the first question, also of 03.07.2018, argued that the rule of exhaustion of local remedies has the "same rationale" underlying it in the two contexts of "broadened" diplomatic protection and in international human rights protection ${ }^{28}$. Yet, it added, under the CERD Convention and other human rights treaties, and under general international law, the effectiveness of local remedies is a component of that rule, which, e.g., determines that such remedies cannot be "unreasonably prolonged" 29 .

41. As to the second question, the applicant State contended that the purpose of the inquiry on "plausibility" of rights, as found in the Court's recent case-law, is a "limited one", not engaging "in any extensive evidentiary inquiry" and not undertaking any "in-depth factual assessment" at the stage of provisional measures; it can only be "a very low threshold" "30. It added that such very low threshold applies, whether the Court puts the requisite "in terms of 'plausibility of rights' or "vulnerability of populations"" to be protected under a human rights treaty like the CERD Convention ${ }^{31}$.

42. The respondent State, for its part, accepted that "violations of human rights" in a "continuing situation" have to be "of concern to the Court". However, - it added, - the issue would "have to be placed within the vision of the Court", i.e., in its view,

"Only States can be parties before the Court in contentious proceedings and the Court when called upon to adjudicate upon a matter has to do so in the light of the rights and duties of those States that are before the Court seeking a legal determination",32.

43. The respondent State added that, as part of ensuring the balance between, on the one hand, vulnerable individuals and groups, and, on the other hand, the "adjudication between States in the light of their rights and obligations under international law" has made the Court to have "recourse inter alia to the doctrine of plausibility". This is, in its view, "a necessary hurdle to be surmounted before tackling substantive issues of protection" of the "rights or interests of individuals, groups or States under perceived threat"; in sum, the consideration of the "plausibility of the rights" at issue is "an indispensable preliminary step needed in order to address claimed violations of rights, whatever their origin" 33 .

44. As to the third question, the applicant State upheld the view that, when there is a continuing situation alleged affecting rights protected under a human rights Convention, "the requirement of a real and imminent risk is necessarily satisfied", and "irreparable prejudice is the natural consequence of restrictions on those rights" 34 . In such circumstances, "any assessment of risk of harm is necessarily met", and the evidence provided (reports "showing continuing harm throughout the past thirteen months", as from 05.06.2017) has been, in its view, "more than sufficient" for the Court "to make a finding of urgency", given the "imminent risk of irreparable harm" 35.

45. For its part, the respondent State argued that, even in case of a continuing situation, the ICJ is to exercise its own functions which are "different from those" of international human rights tribunals at regional levels. Provisional measures, it added cannot be indicated if the Court is not persuaded that the rights invoked are "at least plausible". In its view, "the existence of a continuing situation allegedly affecting rights protected under a human rights treaty does not as such change or modify the conditions required for the indication of provisional measures of protection" 36 .

46. Still in the same week, the contending parties provided the Court, two days later, with their additional written comments (of 05.07.2018) to each other's respective answers (cf. supra) to my questions. The applicant State recalled the components of effectiveness of local remedies and redress in the rationale of the local remedies rule under human rights treaties, and welcomed the UAE's acceptance of it as well as of the Court's need to be "sensitive and attentive" to a continuing situation in breach of human rights, wherein the harm is "not merely imminent by presently occurring", requiring attention also to "the vulnerability of the affected individuals"37. 
47. The respondent State, for its part, insisted on the requirement of exhaustion of local remedies, and on its position that "doctrine of plausibility" constitutes a "balance" between the claimed violation of rights and the "procedural requirements" to adjudicate inter-State cases ${ }^{38}$. Besides questioning the evidence produced, it did not accept the "low threshold" advanced by Qatar, asserting that there "has to be a tangible or plausible basis" for the claims at issue. And it concluded that, in its view, there is no "different approach" to the grant of provisional measures of protection in cases under human rights treaties ${ }^{39}$.

\section{General Assessment: Rationale of the local Remedies Rule in International Human Rights Protection.}

48. May I now proceed to my own assessment of the arguments surveyed above, presented by the contending parties in their written responses to my questions (supra). To start with, in my understanding, the raising of the rule of exhaustion of local remedies at this early stage is surprising, besides regrettable, due to the fact that the present proceedings are on a request for provisional measures of protection, not on admissibility. The local remedies rule is a condition of admissibility of international claims; it cannot be invoked as a precondition for the consideration of urgent requests of provisional measures of protection.

49. The incidence of the local remedies rule in human rights protection is certainly distinct from its application in the practice of diplomatic protection of nationals abroad; the rule at issue is far from having the dimensions of an immutable or sacrosanct principle of international law. Moreover, the two domains - human rights protection and diplomatic protection - are also distinct, and there is nothing to hinder the application of that rule with greater or lesser rigour in such different domains.

50. Its rationale is quite distinct in the two contexts. In the domain of the safeguard of the rights of the human person, attention is focused on the need to secure the faithful realization of the object and purpose of human rights treaties, and on the need of effectiveness of local remedies; attention is focused, in sum, on the needs of protection. The rationale of the local remedies rule in the context of diplomatic protection is entirely distinct, focusing on the process of exhaustion of such remedies.

51. Local remedies, in turn, form an integral part of the very system of international human rights protection, the emphasis falling on the element of redress rather than on the process of exhaustion. The local remedies rule bears witness of the interaction between international law and domestic law in the present context of protection ${ }^{40}$. We are here before a droit de protection, with a specificity of its own, fundamentally victim-oriented, concerned with the rights of individual human beings rather than of States. Such rights are accompanied by obligations of States.

52. Generally recognized rules of international law (which the formulation of the local remedies rule in human rights treaties refers to), besides following an evolution of their own in the distinct contexts in which they apply, necessarily undergo, when inserted in human rights treaties, a certain degree of adjustment or adaptation, dictated by the special character of the object and purpose of those treaties and by the widely recognized specificity of the international protection of human rights.

Committee on the Elimination of Racial Discrimination (CERD Committee) has deemed it necessary to single out that petitioners are only required to exhaust "remedies that are effective in the circumstances" of the cas d'espèce (cases of M. Lacko versus Slovakia, decision of 09.08.2001, para. 6.2; and of Zentralrat Deutscher Sinti und Roma et al. versus Germany, decision of 22.02.2008, para 7.3).

54. In another case (of D. Durmic versus Serbia and Montenegro), the CERD Committee pointed out that local remedies need not be exhausted if their application "is unreasonably prolonged" (decision of 06.03.2006, para. 6.5). And, in yet another case (of D.R. versus Australia), the CERD Committee considered that none of the proposed local remedies could be effective, and reiterated (decision of 14.08.2009) that

"domestic remedies need not be exhausted if they objectively have no prospect of success. This is the case where under applicable domestic law, the claim would inevitably be dismissed, or where established jurisprudence of the highest domestic tribunals would preclude a positive result" (paras. 6.4-6.5). 
55. The local remedies rule has a rationale of its own under human rights treaties; this cannot be distorted by the invocation of the handling of inter-State cases in the exercise of diplomatic protection, where the local remedies rule has an entirely distinct rationale. The former stresses redress, the latter outlines exhaustion. One cannot deprive a human rights Convention of its effet utile by using the distinct rationale of the rule in diplomatic protection.

56. Contemporary international tribunals share the common mission of realization of justice. There is here a fundamental unity of conception and mission. International human rights tribunals, created by Conventions at regional levels, operate within the conceptual framework of the universality of human rights. International human rights tribunals have been faithful to the rationale of effectiveness of local remedies and redress ${ }^{41}$. There is in this respect a complementarity in outlook between mechanisms of dispute-settlement at U.N. and regional levels, all operating under the conceptualized universality of the rights inherent to the human person.

\section{General Assessment: Implications of a Continuing Situation.}

57. In my understanding, the attempt to create another precondition for provisional measures, as from the socalled "plausibility" of rights, is regrettable. The test of so-called "plausibility" of rights is, in my perception, an unfortunate invention - a recent one - of the majority of the ICJ. In the present proceedings, the so-called "plausibility" of admissibility ${ }^{42}$ is a new and additional unfortunate attempt, this time by the respondent State, to invent an additional "precondition" for provisional measures of protection. In a continuing situation, the rights requiring protection are clearly known, their being no sense to wonder whether they are "plausible".

58. In the consideration of the present request for provisional measures of protection in the case of Application of the CERD Convention (Qatar versus UAE), the question of a continuing situation allegedly affecting the rights of vulnerable persons has deserved particular attention, mainly on the part of the applicant State (which dwelt upon it), but also on the part of the respondent State. Yet, the handling of the matter consumed much time in addressing points which have nothing to do with provisional measures of protection, - such as the undue invocation of the rule of exhaustion of local remedies at this stage of provisional measures, as well as the undue attempt to link the so-called "plausibility" of rights to the so-called "plausibility" of admissibility, as presumed interrelated requirements.

59. It appears that each one feels free to interpret so-called "plausibility" of rights in the way one feels like; this may be due to the fact that the Court's majority itself has not elaborated on what such "plausibility" means. To invoke "plausibility" as a new "precondition", creating undue difficulties for the granting of provisional measures of protection in relation to a continuing situation, is misleading, it renders a disservice to the realization of justice. I shall develop further reflections on provisional measures of protection in continuing situations subsequently in the present Separate Opinion (cf. section XI, infra).

60. The rights to be protected in the cas d'espèce are clearly those invoked under the CERD Convention (Articles 2, 4, 5, 6 and 7). The so-called "plausibility" of rights is surrounded by uncertainties, which are much increased in trying to add to it the so-called "plausibility" of admissibility, undermining provisional measures of protection as jurisdictional guarantees of a preventive character. It is time to awaken and to concentrate attention on the nature of provisional measures of protection, particularly under human rights treaties, to the benefit of human beings experiencing a continuing situation of vulnerability affecting their rights.

61. In the present case we are not in face of rights of States; the rights under the CERD Convention are rights of individuals (accompanied by obligations of States), irrespective of the matter having been brought to the ICJ by a State Party to the Convention. In doing so, the State Party exercises a collective guarantee under the CERD Convention, making use of its compromissory clause in Article 22, which is not amenable to interpretation raising "preconditions". The compromissory clause in Article 22 is to be interpreted bearing in mind the object and purpose of the CERD Convention.

\section{THE CORRECT UNDERSTANDING OF COMPROMISSORY CLAUSES UNDER HUMAN RIGHTS CONVENTIONS.}

62. I have dwelt upon this particular point in depth in my lengthy Dissenting Opinion in the earlier case on Application of the CERD Convention (Georgia versus Russian Federation, Judgment of 01.04.2011), where the Court 
upheld the second preliminary objection and found itself without jurisdiction to examine the case. In my Dissenting Opinion (paras. 1-214), I warned at first that the punctum pruriens judicii was the proper understanding of the compromissory clause (Article 22) of the CERD Convention, for which it is necessary to be attentive to the nature and substance of a human rights treaty like the CERD Convention.

63. Regrettably, in that Judgment of 2011, the Court's majority set a very high threshold (as to the requirement of prior negotiations) for the exercise of jurisdiction on the basis of that human rights treaty, the CERD Convention, losing sight of the nature of this important U.N. human rights treaty, endowed with universality. It advanced the view that Article 22 of the CERD Convention establishes "preconditions" to be fulfilled by a State Party before it may have recourse to this Court, thus rendering access to the ICJ particularly difficult. I added, in my Dissenting Opinion, that this was not in accordance with the Court's (PCIJ and ICJ) own earlier jurisprudence constante, which had never ascribed to that factual element the character of a "precondition" that would have to be fully satisfied, for the exercise of its jurisdiction ${ }^{43}$.

64. It was necessary, - I proceeded, - to turn attention to the sufferings and needs of protection of the affected segments of the population; yet, the Court's majority pursued unfortunately an essentially inter-State, and mostly bilateral, outlook, on the basis of allegedly unfulfilled "preconditions" of its own construction; instead of setting up a higher standard of protection, under the CERD Convention, of individuals in a continuing situation of great vulnerability, it applied, contrariwise, a higher standard of State consent for the exercise of its jurisdiction.

65. One cannot erect, in pursuance of a strictly textual or grammatical reasoning relating to the compromissory clause (Article 22) of the CERD Convention, a mandatory "precondition" for the exercise of the Court's jurisdiction (such as that of prior negotiations), as this amounts to erecting a groundless and most regrettable obstacle to justice. This "precondition", - I proceeded, - finds no support in the Court's own earlier jurisprudence constante, nor in the legislative history of the CERD Convention.

66. I then pointed out, in my aforementioned Dissenting Opinion, that, already at the time that the CERD Convention was being elaborated there were those who supported the compulsory settlement of disputes by the Court. Underlying the general rule of treaty interpretation is the principle ut res magis valeat quam pereat (the so-called effet utile), of much importance in respect of human rights treaties, amongst which the CERD Convention. This latter is a pioneering human rights Convention, endowed with universality, occupying a prominent place in the Law of the United Nations itself. It cannot be a hostage of State consent or discretion (as in the entirely distinct domain of diplomatic protection), in its interpretation and application.

67. Before moving to the next point, may I here add that all obligations under the CERD Convention (including those of providing redress by means of effective local remedies, and of dispute-settlement in inter-State cases thereunder) have a rationale of their own, proper of human rights treaties. There was awareness of that since the time of the travaux préparatoires of the CERD Convention ${ }^{44}$, so as to secure its effectiveness, and safeguard it from attempts at conceptual deconstruction (such as the devising of additional so-called "preconditions") ${ }^{45}$.

\section{VULNERABILITY OF SEGMENTS OF THE POPULATION.}

68. In the present Order that the ICJ has just adopted today, in the case of Application of the CERD Convention (Qatar versus UAE), the Court has correctly granted provisional measures of protection under the CERD Convention, to ensure that families including a Qatari, separated by the measures adopted by the UAE on 05.06.2017, are reunited; that Qatari students, affected by the same measures, complete their education in the UAE, or, if they wish, obtain their educational records to continue their studies elsewhere; and that Qataris, affected by the same measures, have access to national tribunals in the UAE. The CERD Convention itself determines that States Parties are to assure to everyone within their jurisdiction "effective protection and remedies" before national tribunals against any acts of discrimination (Article 6). The provisional measures, as requested in the cas d'espèce, become necessary for the protection of persons in a situation of vulnerability.

69. I have already addressed the principle of non-discrimination and the prohibition of arbitrariness (section III, supra), and my reflections thereon lead me to the next related point to be here considered. Cases as the present one of Application of the CERD Convention (Qatar versus UAE), like the aforementioned previous cases before the ICJ also 
under the CERD Convention (as well as under other human rights treaties), disclose the centrality of the position of the human person in the overcoming of the inter-State paradigm in contemporary international law. The request of provisional measures of protection is here intended to put an end to the alleged vulnerability of the affected persons (potential victims).

70. Human beings in vulnerability are the ultimate beneficiaries of compliance with the ordered provisional measures of protection. However vulnerable, they are subjects of international law. We are here before the new paradigm of the humanized international law, the new jus gentium of our times, sensitive and attentive to the needs of protection of the human person in any circumstances of vulnerability. This is a point which $\mathrm{I}$ have been making in successive Individual Opinions in previous decisions of the ICJ; I feel it sufficient only to refer to them now, with no need to extend further thereon in the present Separate Opinion.

71. To summarize it, in my previous Separate Opinion appended to the ICJ's recent Order (of 19.04.2017) on provisional measures of protection - also under the CERD Convention - in the case of Ukraine versus Russian Federation, I pondered:

"As I have been sustaining along the years, time and time again, provisional measures of protection have an autonomous legal regime of their own. This being so, it is clear to me that human vulnerability is a test even more compelling than 'plausibility' of rights for the indication or ordering of provisional measures of protection. In so acknowledging and sustaining, one is contributing to the ongoing historical process of humanization of contemporary international law" (para. 44).

72. Anticipatory in nature, provisional measures of protection are intended to prevent and avoid irreparable harm in situations of gravity (probability of irreparable harm) and urgency. The extreme vulnerability of the affected persons is an aggravating circumstance, rendering such provisional measures imperative. These latter, in my perception, are not "mesures conservatoires" (as in traditional, old-fashioned and unsatisfactory language), as they do require change, as in the cas d'espèce, so as to put an end to a continuing situation (cf. infra) affecting the rights of persons in utter vulnerability, if not defencelessness.

73. For years I have been sustaining that provisional measures of protection, needed by human beings (under human rights treaties, like the CERD Convention in the cas d'espèce), may become even more than precautionary, being in effect tutelary, particularly for vulnerable persons (potential victims), and directly related to realization of justice itself. Obligations emanating from such ordered measures are not necessarily the same as those ensuing from a Judgment as to the merits (and reparations), they may be entirely distinct (cf. infra). Particularly attentive to human beings in situations of vulnerability, provisional measures of protection, endowed with a tutelary character, appear as true jurisdictional guarantees with a preventive dimension.

\section{TOWARDS THE CONSOLIDATION OF THE AUTONOMOUS LEGAL REGIME OF PROVISIONAL MEASURES OF PROTECTION.}

74. This is one of the aspects, and a significant one, of what I have been calling, - in several (more than twenty) of my Individual Opinions, successively within two international jurisdictions, in the period $2000-2018^{46}$, - the needed conformation of the autonomous legal regime of provisional measures of protection ${ }^{47}$. As I pointed out in my Dissenting Opinion in an ICJ's Order (of 16.07.2013), - at an early stage of the handling of two merged cases opposing two Central American States, - even

"the notion of victim (or of potential victim ${ }^{48}$ ), or injured party, can (...) emerge also in the context proper to provisional measures of protection, parallel to the merits (and reparations) of the cas d'espèce" ${ }^{\text {,9 }}$ (para. 75).

75. I am confident that we are at last moving towards the consolidation of the autonomous legal regime of provisional measures of protection, thus enhancing the preventive dimension of international law. After all, contemporary international tribunals have an important contribution to give to the avoidance or prevention of irreparable harm in situations of urgency, to the ultimate benefit of human beings, and to secure due compliance with the ordered provisional measures of protection ${ }^{50}$. 
76. The component elements of this autonomous legal regime are: the rights to be protected; the corresponding obligations; the prompt determination of responsibility (in case of non-compliance), with its legal consequences, encompassing the duty of reparation for damages. Rights and obligations concerning provisional measures of protection are not the same as those pertaining to the merits of the cases, and the configuration of responsibility with all its legal consequences is prompt, without waiting for the decision on the merits. The notion of victim (or potential victim) itself - may I stress this point - marks presence already at this stage, irrespective of the decision as to the merits (cf. supra).

77. Provisional measures have, in recent years, been protecting growing numbers of persons in situations of vulnerability, transformed into a true jurisdictional guarantee of preventive character ${ }^{51}$. Hence the autonomy of the international responsibility that non-compliance with them promptly generates. A study of the matter encompasses the general principles of law, always of great relevance ${ }^{52}$. Attention is to be focused on the common mission of contemporary international tribunals of realization of justice ${ }^{53}$ as from an essentially humanist outlook ${ }^{54}$.

\section{INTERNATIONAL LAW AND THE TEMPORAL DIMENSION.}

78. A consideration of the aforementioned preventive dimension, furthermore, brings to the fore the time factor, and in particular the relationship between international law and the temporal dimension. Such relationship is an ineluctable one, requiring far more attention than the one dispensed to it by international legal doctrine so far. In effect, the temporal dimension underlies the whole domain of international law, being interpreted and applied within time.

79. It ineluctably encompasses provisional measures of protection. In my Dissenting Opinion appended to the ICJ's Order of 28.05.2009 in the case of the Obligation to Prosecute or Extradite (Belgium versus Senegal), I warned inter alia that "[i]t is imperative to reduce or bridge the décalage between the time of victimized human beings and the time of human justice" (para. 49). Subsequently, I devote the whole of my Separate Opinion (paras. 1-117) appended to the ICJ's Order of 18.07.2011 in the case of the Temple of Préah Vihéar (Cambodia versus Thailand) to distinct aspects of the temporal dimension in international law and its incidence on the granting of provisional measures of protection ${ }^{55}$.

80. After all, it is in the nature of Law to accompany the regulatory function in society undergoing changes, contrary to what legal positivists assume in their static view of the legal order. The evolution of international law - acknowledged by the ICJ in an obiter dictum of its célèbre Advisory Opinion on Namibia (of 21.06.1971, para. 53) - responds to the changing needs of all subjects of international law (including individuals) and of the international community as a whole.

81. The evolving international law is permeated by a major enigma, which, for its part, also permeates the existence of all subjects of law (including individuals): the passage of time. International law, emerging ultimately from human conscience, - the universal juridical conscience, - also has a protective function endowed with a preventive dimension, as illustrated by the significant expansion of provisional measures of protection in recent years ${ }^{56}$. Keeping the passage of time in mind, it is important to prevent or avoid harm that may occur in the future (hence the acknowledgment of potential or prospective victims), as well as to put an end to continuing situations already affecting individual rights. Past, present and future come and go together.

\section{PROVISIONAL MEASURES OF PROTECTION IN CONTINUING SITUATIONS.}

82. In the present case of Application of the CERD Convention (Qatar versus UAE), at this stage of request of provisional measures of protection, there are some other considerations that I deem it fit to present, in this Separate Opinion, with regard to the alleged continuing situation in breach of human rights, in addition to those I have already made (cf. section VI.3, supra). Even if the evidence already presented to the ICJ so far may appear insufficient, there are sources of it that may be regarded relevant to the consideration of such continuing situation at this stage.

83. In this respect, for example, the Report of the United Nations Office of the High Commissioner for Human Rights (OHCHR - of December 2017) ${ }^{57}$, - brought to the attention of the ICJ in the present proceedings, - gave an account of a continuing situation (an "ongoing crisis on human rights", with "continuing implications", and "cases of 
temporary or potentially durable separation of families", among other "long-standing human rights issues", to the detriment, e.g., of "migrant workers") ${ }^{58}$.

84. The OHCHR, having decided to monitor in loco the consequences on human rights of the UAE's decision or announcement of 05.06.2017, reported, one semester later, on the suspension and "considerable restrictions" on freedom of movement "to and from Qatar" (paras. 23 and 26), with "continuing implications to date"; such restrictions disrupted family life, affected the right to education, as Qatari students were prevented from pursuing their studies where they were (paras. 26 and 50). The aforementioned OHCHR Report (of December 2017) referred to "cases of temporary or potentially durable separation of families", with all their consequences (para. 32).

85. There was also an impact on the right to health, with humanitarian consequences (para. 43), as some people had to travel abroad to receive their medical treatment or to undergo surgery (para. 44). As to the restrictions on freedom of expression, the OHCHR reported that the unilateral measures have been accompanied by a "widespread defamation and hatred campaign against Qatar and Qataris in various media" (paras. 14 and 19). The Report, furthermore, addressed another long-standing human rights issue, affecting the rights of migrant workers and non-citizens (paras. 54-58). The Report at last considered the restrictive unilateral measures as arbitrary (para. 60).

86. Likewise, a Joint Communication from the U.N. Special Procedures Mandate Holders of the U.N. Human Rights Council to the UAE ${ }^{59}$, of 18.08.2017, the Special Rapporteurs warned that the decision announced by the UAE on 05.06.2017 "has threatened the most vulnerable groups, including women, children, persons with disabilities and older persons" (p. 1). It has, furthermore, - it continued, - led to the separation of families, the interruption of studies in schools or universities, and has also affected the right to health (pp. 2-3 and 5), among others. The Special Rapporteurs then drew attention to "the urgency of the matter" and the "extreme gravity" of the situation, and urged that "all necessary interim measures be taken to halt the alleged violations and prevent their reoccurrence" (p. 7).

87. Among other reports referred to in the course of the present proceedings before the ICJ, were those of non-governmental organizations (NGOs) with much experience at international level, such as, inter alia, Amnesty International and Human Rights Watch. In its very recent Report (of 05.06.2018), Amnesty International referred to the situation of continuity harming separated families, and individuals (among whom migrant workers, children and students) ${ }^{60}$. Accordingly, it called upon the States concerned ${ }^{61}$ to "immediately lift all arbitrary restrictions" imposed on Qatari nationals, and to respect human rights ${ }^{62}$.

88. For its part, Human Rights Watch, in its earlier Report (of 12.07.2017), likewise warned against "human rights violations" in the separation of families, the deprivation of migrant workers, the discrimination against women, the interruption of medical treatment, and the interruption of education ${ }^{63}$. Both Human Rights Watch and Amnesty International have provided accounts, in their respective reports, of information obtained from interviews with those victimized in loco.

89. In effect, the continuing situation in breach of human rights is a point which has had an incidence in other cases before the ICJ as well, at distinct stages of the proceedings. May I briefly recall here three examples, along the last decade. In the case concerning the Obligation to Prosecute or Extradite (Belgium versus Senegal), as the ICJ in its Order of 28.05.2009 decided not to indicate provisional measures, I appended thereto a Dissenting Opinion, wherein - as already pointed out (para. 79, supra) - I drew attention to the décalage to be bridged between the time of human beings and the time of human justice (paras. 35-64).

90. Urgency and probability of irreparable damage, - I proceeded, - were quite clear, in the continuing situation of lack of access to justice of the victims of the Hissène Habré regime (1982-1990) in Chad. This right of access to justice assumed a "paramount importance" (paras. 29 and 74-77), - I added, - in the cas d'espèce, under the U.N. Convention against Torture; furthermore, I dwelt upon the component elements of the autonomous legal regime of provisional measures of protection (paras. 8-14, 26-29 and 65-73). Such measures were necessary for the safeguard of the right to the realization of justice (paras. 78-96 and 101).

91. In the case on Jurisdictional Immunities of the State (Germany versus Italy), as the ICJ, in its Order of 06.07.2010 found the counter-claim of Italy inadmissible, once again I appended thereto a Dissenting Opinion, wherein I examined at depth the notion of "continuing situation" in the factual context of the cas d'espèce, as 
debated between the contending parties (paras. 55-59 and 92-100). My Dissenting Opinion encompassed the origins of a "continuing situation" in international legal doctrine (paras. 60-64); the configuration of a "continuing situation" in international litigation and case-law (paras. 65-83); the configuration of a "continuing situation" in international legal conceptualization at normative level (paras. 84-91).

92. And, once again, I warned against the pitfalls of State voluntarism (paras. 101-123). Suffice it here only to refer to my lengthy reflections on the notion of "continuing situation" in the case on Jurisdictional Immunities of the State, as I see no need to reiterate them expressis verbis herein. What cannot pass unnoticed is that a continuing situation in breach of human rights has had an incidence at distinct stages of the proceedings before the ICJ: in addition to decisions - as just seen - on provisional measures and counter-claim (supra), it has also been addressed in decision as to the merits.

93. This is illustrated by the aforementioned case of A.S. Diallo (Guinea versus D.R. Congo, merits, Judgment of 30.11.2010). Its factual context disclosed a continuing situation of breaches of Mr. A.S. Diallo's individual rights in the period extending from 1988 to 1996. The griefs suffered by the victim extended in time (the arrests and detentions of 1988-1989 followed by those of 1995-1996, prior to his expulsion from the country of residence), in breach of the relevant provisions of human rights treaties (the U.N. Covenant on Civil and Political Rights and the African Charter on Human and Peoples' Rights) as well as Article 36(1)(b) of the Vienna Convention on Consular Relations). His griefs were surrounded by arbitrariness on the part of State authorities ${ }^{64}$, and amounted to a wrongful continuing situation, marked by the prolonged lack of access to justice.

\section{EPILOGUE: A RECAPITULATION.}

94. This is, as seen, the third case under the CERD Convention in which provisional measures of protection have been rightly ordered by the ICJ, in this new era of its international adjudication of human rights cases. The fact that a case is an inter-State one, characteristic of the contentieux before the ICJ, does not mean that the Court is to reason likewise on a strictly inter-state basis. Not at all. It is the nature of a case that will call for a reasoning, so as to reach a solution. The present case of Application of the CERD Convention (Qatar versus UAE) concerns the rights protected thereunder, which are the rights of human beings, and not rights of States.

95. This has a direct bearing on the consideration of a request for provisional measures of protection under a human rights Convention. Provisional measures, with a preventive dimension, have been undergoing a significant evolution, moving further towards the consolidation of the autonomous legal regime of their own, to the benefit of the titulaires of rights. In another endeavour to keep paving this path, may I, last but not least, proceed to a brief recapitulation of the main points I deemed it fit to make, particularly in respect of such provisional measures, under the CERD Convention, in the course of the present Separate Opinion.

96. Primus: The principle of equality and non-discrimination lies in the foundations of the rights protected under the CERD Convention also by means of provisional measures. The historical formation of the corpus juris of international protection of human rights has much contributed to a growing awareness of the importance of the prevalence of the basic principle of equality and non-discrimination. Secundus: The work of U.N. supervisory organs - among which the CERD Committee - bears witness of such growing awareness.

97. Tertius: It is necessary nowadays that the advances in respect of the basic principle of equality and nondiscrimination, at normative and jurisprudential levels, are also accompanied by the international legal doctrine, which so far has not dedicated sufficient attention to that fundamental principle. Quartus: The protection sought under the CERD Convention is also against arbitrariness, as in the cas d'espèce. This point has not escaped the attention of other international tribunals, entrusted with the interpretation and application of distinct human rights Conventions.

98. Quintus: Human rights treaties, - including the CERD Convention, conform a Law of protection (a droit de protection), oriented towards the safeguard of the ostensibly weaker party (the real or potential victim), and the prohibition of arbitrary measures, so as also to secure the prevalence of the rule of law (la prééminence du droit). Sextus: As to the points discussed in the present proceedings of the cas d'espece, there are two of them that require clarification: the rationale of the local remedies rule in the international protection of human rights, and the implications of a continuing situation affecting or breaching human rights. 
99. Septimus: The local remedies rule, as a condition of admissibility of international claims, cannot be invoked as a "precondition" for the consideration of urgent requests of provisional measures of protection. Octavus: The rationale of the local remedies rule in human rights protection is entirely distinct from that of its application in the practice of diplomatic protection of nationals abroad: in human rights protection the rule is focused on effectiveness of local remedies and redress, while in diplomatic protection it is focused on the process of exhaustion of such remedies.

100. Nonus: The CERD Committee itself has underlined the components of effectiveness of local remedies and redress. Human rights protection is victim-oriented, it is a Law of protection of the weaker party (droit de protection), as upheld by international human rights tribunals; discretionary diplomatic protection, for its part, remains Stateoriented. Decimus: There is no ground for attempting to add, to the so-called "plausibility" of rights, the so-called "plausibility" of admissibility, as an additional "precondition" for provisional measures of protection.

101. Undecimus: In a continuing situation, the rights requiring protection are clearly known, their being no sense to wonder whether they are "plausible". Duodecimus: The proper understanding of compromissory clauses under human rights Conventions is necessarily attentive to the nature and substance of those Conventions, as well as to their object and purpose; such clauses cannot be interpreted attempting to find "preconditions", rendering access to justice under human rights Conventions particularly difficult.

102. Tertius decimus: The aforementioned prohibition of arbitrariness brings to the fore the issue of the vulnerability of those affected by discriminatory measures; requests of provisional measures of protection, in cases like the present, are intended to put an end to a continuing situation of vulnerability of the affected persons (potential victims). Quartus decimus: Human vulnerability is a test more compelling than so-called 'plausibility' of rights for the ordering of provisional measures of protection under human rights treaties.

103. Quintus decimus: There has been an advance towards the consolidation of what I have been calling, along the years, the autonomous legal regime of provisional measures of protection. Sextus decimus: Provisional measures of protection have, in recent years, been protecting growing numbers of persons in situations of vulnerability; they have thus been transformed into a true jurisdictional guarantee of preventive character. Septimus decimus: Such preventive character brings to the fore the temporal dimension in the application of the provisional measures of protection, e.g., when they are intended, as in the present case, to put an end to a continuing situation affecting individual rights.

104. Duodevicesimus: In respect of the present case, there have been U.N. reports and other documents giving accounts of a continuing situation affecting human rights under the CERD Convention. Undevicesimus: The continuing situation in breach of human rights is a point which has had an incidence in earlier cases before the ICJ as well, at distinct stages of the proceedings. Vicesimus: The determination and ordering of provisional measures of protection under human rights Conventions can only be properly undertaken from a humanist perspective, necessarily avoiding the pitfalls of an outdated and impertinent State voluntarism.

(Signed) Antônio Augusto CANÇADO TRINDADE.

\section{ENDNOTES}

1 ICJ's Judgment of 01.04.2011, - preceded by the ICJ's Order of provisional measures of protection, of 15.10.2008, wherein the Court acknowledged that there was an ongoing unresolved problem in the conflict in the region, and the persons affected remained vulnerable (paras. 142-143).

2 ICJ's Order of 19.04.2017, to which I appended a Separate Opinion; earlier, to the ICJ's Judgment of 01.04.2011 I appended a Dissenting Opinion.
3 Particularly relevant, for a study of the right to freedom of movement and residence under Article 22 of the American Convention on Human Rights, are the Judgment of the Inter-American Court of Human Rights (IACtHR) of 15.06.2005, in the case of the Moiwana Community versus. Suriname (paras. 107-121), as well as the IACtHR's Order (on provisional measures of protection), of 18.08.2000, in the case of Haitians and Dominicans of Haitian-Origin in 
the Dominican Republic (paras. 9-11), and Concurring Opinion of Judge A.A. Cançado Trindade (paras. 2-25). Cf. likewise Qatar's Application Instituting Proceedings (of 11.06 .2018 ) p. 41 , para. 58 ; and cf. p. 50, para. 65.

5 There are three brief references, in the oral pleadings of Qatar, to the principle of respect for the "dignity and equality inherent in all human beings"; cf. ICJ, CR 2018/12, of 27.06.2018, pp. 32,35 and 59 .

6 Cf., e.g., A.A. Cançado Trindade, "Address to the U.N Human Rights Committee on the Occasion of the Commemoration of Its 100th Session", 29 Netherlands Quarterly of Human Rights (2011) pp. 131-137.

7 Including at inter-individual level; cf. W. Vandenhole, NonDiscrimination and Equality in the View of the U.N. Human Rights Treaty Bodies, Antwerpen/Oxford, Intersentia, 2005, pp. 23 and 215 .

8

To the study of which I have dedicated my extensive book: A.A. Cançado Trindade, El Principio Básico de Igualdad y No-Discriminación: Construcción Jurisprudencial, 1st. ed., Santiago de Chile, Ed. Librotecnia, 2013, pp. 39-748.

9 The IACtHR upheld that, accordingly, any discriminatory treatment of undocumented migrants or aliens would generate the international responsibility of States.

10 For a study of the matter, cf., e.g., A.A. Cançado Trindade, "Le déracinement et la protection des migrants dans le Droit international des droits de l'homme", 19 Revue trimestrielle des droits de l'homme - Bruxelles (2008) n. 74, pp. 289328.

11 Ever since the IACtHR upheld, in its Advisory Opinion n. 18 (of 17.09.2003), that the fundamental principle of equality and non-discrimination entered into the domain of jus cogens (supra), in the adjudication of successive contentious cases I stressed the need to enlarge further the material content of jus cogens, so as to encompass likewise the right of access to justice, and fulfill the pressing needs of protection of the human person. I did so, inter alia, in my Separate Opinion (dedicated on the right of access to justice lato sensu) in the Court's Judgment (of 31.01.2006) in the case of the Massacre of Pueblo Bello versus Colombia, drawing attention to the utmost importance of the right of access to justice lato sensu, encompassing its full realisation (para. 64). I further stressed, on successive occasions, the special needs of protection of victims in situations of vulnerability; cf. A.A. Cançado Trindade, El Ejercicio de la Función Judicial Internacional Memorias de la Corte Interamericana de Derechos Humanos, 5th. rev. ed., Belo Horizonte, Edit. Del Rey, 2018, ch. XXIV, pp. 219-226.

12 Cf., on the part of the applicant State, ICJ, doc. CR 2018/12, of 27.06.2018, pp. 22-23; ICJ, doc. CR 2018/14, of 29.06.2018, p. 30.

13 Such as, e.g. the right not to be expelled arbitrarily from a country, the right to a fair trial, the right to respect for private and family life, the right to an effective remedy, or any other protected right.

14 ICJ, CR 2018/12, of 27.06.2018, pp. 16-19, 22, 29-30, $38-40,42,46,50,52-58$ and $62-64$ (on the continuity of violations).
16

17 facts"), p. 31 (on "prima facie determination on the admissibility of the claims" and so-called plausibility of admissibility), and pp. 22-35 (on pre-conditions of admissibility).

18 Ibid., pp. 28-35.

19 Cf., on the part of Qatar, ICJ, CR 2018/14, of 29.06.2018, pp. 17-20; and cf., on the part of the UAE, ICJ, CR 2018/15, of 29.06.2018, pp. $17-18$

20 Cf., on the part of Qatar, ICJ, CR 2018/14, of 29.06.2018, pp. 36-37 and 39-41.

21 In: ICJ, CR 2018/15, of 29.06.2018, p. 45.

22 ICJ, doc. 2018/24, of 03.07.2018, response in letter of Qatar, pp. 1-2, paras. 3-4.

23 See A.A. Cançado Trindade, The Application of the Rule of Exhaustion of Local Remedies in International Law (1983), pp. 39, 51-52, 56.

24 This added purpose for the local remedies rule necessarily informs its application under the Convention and other human rights treaties, as Qatar will explain at the appropriate stage of these proceedings.

25 ICJ, doc. 2018/24, of 03.07.2018, response in letter of Qatar, p. 3, paras. 5-6.

26

Ibid., pp. 4-6, paras. 7-8 and 11 .

27 Ibid., pp. 6-7, para. 12.

28 ICJ, doc. 2018/24, of 03.07.2018, response in letter of the UAE, p. 1

29 Ibid., p. 2

30 ICJ, doc. 2018/24, of 03.07.2018, response in letter of Qatar, pp. 10-16, paras. 19, 21, 23 and 28 .

31 Ibid, pp. 13-16, paras. 26-29.

32 ICJ, doc. 2018/24, of 03.07.2018, response in letter of the UAE, p. 3.

33 Ibid., p. 3.

34 ICJ, doc. 2018/24, of 03.07.2018, response in letter of Qatar, p. 17 , paras. $31-32$.

35 Ibid., pp. 19-20, paras. 35-36.

36 And it added that " $[\mathrm{t}]$ he UAE is focused upon the importance of the implementation of binding treaties and the fight against terrorism". ICJ, doc. 2018/24, of 03.07.2018, response in letter of the UAE, p. 5.

37 ICJ, doc. 2018/25, of 05.07.2018, comment in letter of Qatar, pp. $1-4$, paras. $2-5$ and $7-8$.

38 ICJ, doc. 2018/25, of 05.07.2018, comment in letter of the UAE, pp. 1-3

39 Ibid., pp. 4-8.

40 Cf. A.A. Cançado Trindade, The Application of the Rule of Exhaustion of Local Remedies in International Law, Cambridge, Cambridge University Press, 1983, pp. 1-445; A.A. Cançado Trindade, $O$ Esgotamento de Recursos Internos no Direito Internacional, $2^{\text {nd }}$. ed., Brasília, Edit. University of Brasília, 1997, pp. 1-327; A.A. Cançado Trindade, "Origin and Historical Development of the Rule of Exhaustion of Local Remedies in International Law", 12 Revue belge de 
droit international/Belgisch Tijdschrift voor international Recht - Bruxelles (1976) pp. 499-527.

41 To this effect, cf., for an analysis of the vast case-law of the ECtHR on the matter, e.g., P. van Dijk, F. van Hoof, A. van Rijn and Leo Zwaak, Theory and Practice of the European Convention on Human Rights, 4th. ed., Antwerpen/Oxford, Intersentia, 2006, pp. 125-161 and 560-563; D.J. Harris, M. O'Boyle, E.P. Bates and C.M. Buckley, Law of the European Convention on Human Rights, 2nd. ed., Oxford, Oxford University Press, 2009, pp. 759-776; as to the case-law of the IACtHR, cf. A.A. Cançado Trindade, El Agotamiento de los Recursos Internos en el Sistema Interamericano de Protección de los Derechos Humanos, San José/C.R., IIDH, 1991, pp. 1-60; and as to the case-law of the African Court on Human and Peoples' Rights (AfCtHPR), cf. M. Löffelmann, Recent Jurisprudence of the African Court on Human and Peoples' Rights-Developments 2014 to 2016, Arusha, Tanzania/Eschborn, Germany, Deutsche Gesellschaft für Internationale Zusammenarbeit (GIZ), 2016, pp. 1-63, esp. pp. 5-8, 22, 24-26 and 29-30.

Cf., on the part of the UAE, ICJ, CR 2018/15, of 29.06.2018, p. 16.

43 Both the PCIJ and the ICJ have been quite clear in holding that an attempt of negotiation is sufficient, there being no mandatory "precondition" at all of resolutory negotiations for either of them to exercise jurisdiction in a case they had been seized of.

44 Cf., on this particular point, e.g., N. Lerner, The U.N. Convention on the Elimination of All Forms of Racial Discrimination (reprint revised), Leiden, Brill/Nijhoff, 2014, pp. 81 and 98; A. A. Cançado Trindade, "Exhaustion of Local Remedies under the United Nations Convention on the Elimination of All Forms of Racial Discrimination", 22 German Yearbook of International Law/Jahrbuch für internationales Recht - Kiel (1979) pp. 374-383;

45 Cf. recent assessments by, e.g., M. Dubuy, "Application de la Convention internationale sur l'élimination de toutes les formes de discrimination raciale (Géorgie c. Fédération de Russie), exceptions préliminaires: Un formalisme excessif au service du classicisme?", 57 Annuaire français de Droit international (2011) pp. 183-212; P. Thornberry, The International Convention on the Elimination of All Forms of Racial Discrimination - A Commentary, Oxford, Oxford University Press, 2016, pp. 472-483 (on Article 22).

46 Such Individual Opinions on the matter are reproduced in the collections: a) Judge A.A. Cançado Trindade - The Construction of a Humanized International Law - A Collection of Individual Opinions (1991-2013), vol. I (IACtHR), Leiden, Brill/Nijhoff, 2014, pp. 799-852; vol. II (ICJ), Leiden, Brill/Nijhoff, 2014, pp. 1815-1864; vol. III (ICJ), Leiden, Brill/Nijhoff, 2017, pp. 733-764; and b) Vers un nouveau jus gentium humanisé - Recueil des Opinions Individuelles du Juge A.A. Cançado Trindade [CIJ], Paris, L'Harmattan, 2018, pp. 143-224 and 884-886; and c) Esencia $y$ Transcendencia del Derecho Internacional de los Derechos Humanos (Votos [del Juez A.A. Cançado Trindade] en la Corte Interamericana de Derechos Humanos, 1991-2008), vols. I-III, 2nd. rev. ed., Mexico D.F., Ed. Cám. Dips., 2015, vol. III, pp. 77-399.

47 Cf. A.A. Cançado Trindade, O Regime Jurídico Autônomo das Medidas Provisórias de Proteção, The Hague/Fortaleza, IBDH/IIDH, 2017, pp. 13-348.
48

On the notion of potential victims in the framework of the evolution of the notion of victim or the condition of the complainant in the domain of the international protection of human rights, cf. A.A. Cançado Trindade, "Co-Existence and Co-Ordination of Mechanisms of International Protection of Human Rights (At Global and Regional Levels)", 202 Recueil des Cours de l'Académie de Droit International de La Haye (1987), ch. XI, pp. 243-299, esp. pp. 271-292.

49 Cf. ICJ, (merged) cases of Certain Activities Carried out by Nicaragua in the Border Area (Costa Rica versus Nicaragua) and Construction of a Road in Costa Rica along the San Juan River, Order of 16.07.2013, Dissenting Opinion of Judge Cançado Trindade, para. 75 .

50 Cf., to this effect, ICJ, (merged) cases of Certain Activities Carried out by Nicaragua in the Border Area (Costa Rica versus Nicaragua) and Construction of a Road in Costa Rica along the San Juan River, Order of 22.11.2013, Separate Opinion of Judge Cançado Trindade, paras. 20-31 and 40. The right of access to justice, also in the present domain (cf. para. 68, supra), is to be understood lato sensu, encompassing not only the formal access to a competent tribunal, but also the due process of law (equality of arms), and the faithful compliance with the decision; for a general study, cf. A.A. Cançado Trindade, El Derecho de Acceso a la Justicia en Su Amplia Dimensión, 2nd. ed., Santiago de Chile, Ed. Librotecnia, 2012, pp. 79-574; A.A. Cançado Trindade, The Access of Individuals to International Justice, Oxford, Oxford University Press, 2011, pp. 1-236.

51 Cf. A.A. Cançado Trindade, Tratado de Direito Internacional dos Direitos Humanos, vol. III, Porto Alegre, S.A. Fabris Ed., 2003, pp. 80-83; A.A. Cançado Trindade, "Les mesures provisoires de protection dans la jurisprudence de la Cour Interaméricaine des Droits de l'Homme", in Mesures conservatoires et droits fondamentaux (eds. G. Cohen Jonathan and J.-F. Flauss), Bruxelles, Bruylant/Nemesis, 2005, pp. 145-163; A.A. Cançado Trindade, "The Evolution of Provisional Measures of Protection under the Case-Law of the Inter-American Court of Human Rights (1987-2002)", 24 Human Rights Law Journal - Strasbourg/Kehl (2003), n. 5-8, pp. 162-168; A.A. Cançado Trindade, "La Expansión y la Consolidación de las Medidas Provisionales de Protección en la Jurisdicción Internacional Contemporánea", in Retos de la Jurisdicción Internacional (eds. S. Sanz Caballero and R. Abril Stoffels), Cizur Menor/Navarra, Cedri/CEU/Thomson Reuters, 2012, pp. 99-117.

52 Cf., e.g., inter alia, A.A. Cançado Trindade, Princípios do Direito Internacional Contemporâneo, 2nd. rev. ed., Brasília, FUNAG, 2017, pp. 25-454; A.A. Cançado Trindade, "Foundations of International Law: The Role and Importance of Its Basic Principles", in XXX Curso de Derecho Internacional Organizado por el Comité Jurídico Interamericano - OAS (2003) pp. 359-415.

53 A.A. Cançado Trindade, Os Tribunais Internacionais e a Realização da Justiça, 2nd. ed., Belo Horizonte, Edit. Del Rey, 2017, pp. 29-468.

54 Cf. A.A. Cançado Trindade, A Visão Humanista da Missão dos Tribunais Internacionais Contemporâneos, The Hague/ Fortaleza, IBDH/IIDH, 2016, pp. 11-283; A.A. Cançado Trindade, Los Tribunales Internacionales Contemporáneos y la Humanización del Derecho Internacional, Buenos Aires, Ed. Ad-Hoc, 2013, pp. 7-185.

55 I pondered inter alia that, when the protection by means of provisional measures is intended to extend to "the spiritual 
needs of human beings", bringing to the fore, as in the cas d'espèce, "the safeguard of cultural and spiritual world heritage", the time dimension is even wider, bringing back "timelessness" (para. 101).

56 Cf. A.A. Cançado Trindade, International Law for Humankind - Towards a New Jus Gentium, $2^{\text {nd }}$. rev. ed., Leiden/ The Hague, Nijhoff/The Hague Academy of International Law, 2013, pp. 31-34, 38-47 and 50-51.

57 The OHCHR Technical Mission visited Qatar on 17-24.11.2017, where it conducted its research on documents provided by distinct entities, besides interviews with "about 40 individuals" (paras. 4-6).

58 Paragraphs 4(i), 26, 32-33 and 54, respectively. The Report reiteratedly referred to the problem of continuing separations of families (paras. 32-33, 37 and 64). It warned that "measures targeting individuals on the basis of their Qatari nationality or their links with Qatar can be qualified as non-disproportionate and discriminatory" (para. 61). It further warned that such unilateral measures were "premeditated" and "accompanied by a widespread defamation and hatred campaign" (paras. 14-15).

59 Namely: Special Rapporteur on the human rights of migrants; Special Rapporteur on the promotion and protection of the right to freedom of opinion and expression; Special Rapporteur on the right of everyone to the enjoyment of the highest attainable standard of physical and mental health; Special Rapporteur on contemporary forms of racism, racial discrimination, xenophobia and related intolerance;
Special Rapporteur on the promotion and protection of human rights while countering terrorism; and Special Rapporteur on the right to education (pursuant to U.N. Human Rights Council resolutions 34/18, 33/9, 34/21, 34/35, 31/3, and 26/17).

60 Amnesty International, [Report:] One Year Since the Gulf Crisis, Families are Left Facing an Uncertain Future, of 05.06.2018, p. 1 .

61 The UAE, Saudi Arabia and Bahrain.

62 Amnesty International, op. cit. supra n. (60), p. 3.

63 Human Rights Watch, [Report:] "Qatar: Isolation Causing Rights Abuses", of 12.07.2017, pp. 1, 3-4 and 6-10.

64 At the time of his arrests and detention. Mr. A.S. Diallo was not informed of the charges against him, nor could he have availed himself without delay of his right to information on consular assistance. - For its part, the CERD Committee, in its practice, has also been particularly attentive to the prohibition of discriminatory measures against members of vulnerable groups (such as, e.g., migrants); cf. R. de Gouttes, "Regards comparatifs sur deux organes internationaux chargés de la lutte contre le racisme: le Comité des Nations Unies pour ĺÉlimination de la Discrimination Raciale (CERD) et la Commission Européenne contre le Racisme et ÍIntolérance (ECRI)", in Réciprocité et universalité: Sources et regimes du Droit international des droits de lhomme Mélanges en ĺhonneur du Prof. E. Decaux, Paris, Pédone, 2017, pp. 1015-1022, esp. pp. 1017 and 1020. 


\section{DISSENTING OPINION OF JUDGE BHANDARI}

1. On a close and careful examination of the pleadings, documents and submissions, I came to the conclusion that, in the facts and circumstances of this case, the Court should not have indicated provisional measures.

2. The case of Qatar is based on the UAE's declaration of 5 June 2017, which is reproduced in relevant part as under:

"UAE affirms its complete commitment and support to the Gulf Cooperation Council and to the security and stability of the GCC States. Within this framework, and based on the insistence of the State of Qatar to continue to undermine the security and stability of the region and its failure to honour international commitments and agreements, it has been decided to take the following measures that are necessary for safeguarding the interests of the GCC States in general and those of the brotherly Qatari people in particular:

1- In support of the statements issued by the sisterly Kingdom of Bahrain and sisterly Kingdom of Saudi Arabia, the United Arab Emirates severs all relations with the State of Qatar, including breaking off diplomatic relations, and gives Qatari diplomats 48 hours to leave UAE.

2- Preventing Qatari nationals from entering the UAE or crossing its points of entry, giving Qatari residents and visitors in the UAE 14 days to leave the country for precautionary security reasons. The UAE nationals are likewise banned from traveling to or staying in Qatar or transiting through its territories.

3- Closure of UAE airspace and seaports for all Qataris in 24 hours and banning all Qatari means of transportation, coming to or leaving the UAE, from crossing, entering or leaving the UAE territories, and taking all legal measures in collaboration with friendly countries and international companies with regards to Qataris using the UAE airspace and territorial waters, from and to Qatar, for national security considerations.

The UAE is taking these decisive measures as a result of the Qatari authorities' failure to abide by the Riyadh Agreement on returning GCC diplomats to Doha and its Complementary Arrangement in 2014, and Qatar's continued support, funding and hosting of terror groups, primarily Islamic Brotherhood, and its sustained endeavours to promote the ideologies of Daesh and Al Qaeda across its direct and indirect media."1

3. The UAE made unqualified statements that the declaration of 5 June 2017 has not been implemented or given effect to ${ }^{2}$. Conversely, Qatar could not produce sufficiently cogent evidence, in writing or orally, to demonstrate that the declaration of 5 June 2017 has been implemented. Furthermore, on 5 July 2018, after the closure of the oral proceedings, the UAE's Ministry of Foreign Affairs made an unqualified undertaking. The relevant portion of this undertaking states that:

"[s]ince its announcement on June 5, 2017, pursuant to which the United Arab Emirates (UAE) took certain measures against Qatar for national security reasons, the UAE has instituted a requirement for all Qatari citizens overseas to obtain prior permission for entry into the UAE. Permission may be granted for a limited-duration period, at the discretion of the UAE government.

The UAE Ministry of Foreign Affairs and International Cooperation wishes to confirm that Qatari citizens already resident in the UAE need not apply for permission to continue residence in the UAE. However, all Qatari citizens resident in the UAE are encouraged to obtain prior permission for re-entry into UAE territory."

4. In view of the UAE's explanation that the declaration of 5 June 2017 has not been implemented, and of the unilateral undertaking of 5 July 2018, the risk of irreparable prejudice to the rights of Qatar is not apparent. Unilateral undertakings before the Court can create obligations under international law, as the Court confirmed in Nuclear 
Tests (Australia v. France) $)^{3}$, Nuclear Tests (New Zealand v. France) $)^{4}$, and Maritime Dispute (Peru v. Chile) ${ }^{5}$. Such undertakings can also have an impact on provisional measures proceedings, if made in the context of such proceedings, as it emerges from the jurisprudence of the Court and of the International Tribunal for the Law of the Sea (ITLOS).

5. In Questions relating to the Obligation to Prosecute or Extradite (Belgium v. Senegal), the Co-Agent of Senegal made a solemn declaration under which: "Senegal will not allow Mr. Habré to leave Senegal while the present case is pending before the Court. Senegal has not the intention to allow Mr. Habré to leave the territory while the present case is pending before the Court"

The Court held that, "taking note of the assurances given by Senegal . . . the risk of irreparable prejudice to the rights claimed by Belgium is not apparent on the date of this Order" ${ }^{\text {" }}$. In Questions relating to the Seizure and Detention of Certain Documents and Data (Timor-Leste v. Australia), the Attorney-General of Australia made a written undertaking, under which the documents seized from Timor-Leste's legal counsel would "not be used by any part of the Australian Government for any purpose other than national security purposes" $"$. The Court held that, "[g]iven that, in certain circumstances involving national security, the Government of Australia envisages the possibility of making use of the seized material ... there remains a risk of disclosure of this potentially highly prejudicial information"?.

6. In Land Reclamation by Singapore in and around the Straits of Johor (Malaysia v. Singapore), heard by ITLOS under Article 290 of the United Nations Convention on the Law of the Sea ${ }^{10}$, the Agent of Singapore made a "commitment", according to which:

"[i]f . . Malaysia believes that Singapore had missed some point or misinterpreted some data and can point to a specific and unlawful adverse effect that would be avoided by suspending some part of the present works, Singapore would carefully study Malaysia's evidence. If the evidence were to prove compelling, Singapore would seriously re-examine its works and consider taking such steps as are necessary and proper, including a suspension, . . . to deal with the adverse effect in question." 11

ITLOS placed on record the commitment made by Singapore ${ }^{12}$. However, it seems that ITLOS did not consider that such a commitment was sufficient to remove the risk of irreparable prejudice, since it unanimously prescribed provisional measures ${ }^{13}$.

7. The jurisprudence suggests that, in order to remove the risk of irreparable prejudice, an undertaking or commitment must be unqualified. Australia's solemn undertaking was insufficient because it stated that the documents allegedly belonging to Timor-Leste could be used if national security so required. Similarly, Singapore's commitment appears to have been insufficient because it was worded in vague terms, as it stated that Singapore "would carefully study" available evidence, and only "[i]f the evidence were to prove compelling", Singapore pledged that it "would seriously re-examine its works". By contrast, the undertaking of the Co-Agent of Senegal was unqualified, as it did not list any circumstances under which Mr. Habré would have been allowed to leave Senegal.

8. In the present case, the unqualified undertaking included in the statement of the UAE's Ministry of Foreign Affairs of 5 July 2018 does not seem to have been qualified by any exceptions. In this sense, it is similar to the undertaking in Questions relating to the Obligation to Prosecute or Extradite (Belgium v. Senegal), and different from the undertakings in Questions relating to the Seizure and Detention of Certain Documents and Data (Timor-Leste v. Australia) and Land Reclamation by Singapore in and around the Straits of Johor (Malaysia v. Singapore). Qataris already residing in the UAE "need not apply for permission to continue residence in the UAE", while only being encouraged to "obtain prior permission for re-entry into UAE territory". Based on this wording, it would appear that Qataris residing in the UAE, but currently located outside the UAE, can re-enter the UAE without hindrance. Qataris residing overseas are required "to obtain prior permission for entry into the UAE". The granting of right to entry and right of abode to any foreign citizen is a prerogative falling within the reserved domain of the UAE. Consequently, that "permission may be granted . . . at the discretion of the UAE government" could not be seen as an exception to the undertaking that residing Qataris may continue legally to 
reside in the UAE, and that non-residing Qataris need to obtain permission to enter the UAE. In the light of this undertaking, it is my view that there is no irreparable prejudice in the circumstances of this case.

9. The existence of urgency in a request for provisional measures is fundamentally fact-dependent. The unqualified undertaking by the UAE, which I believe to have removed the risk of irreparable prejudice in the circumstances, has an impact on urgency. If there is no irreparable prejudice, there can be no urgency, since urgency is to be understood as an attribute of irreparable prejudice. In the most recent orders on provisional measures, the Court has consistently stated that urgency is a "real and imminent risk that irreparable prejudice will be caused to the rights in dispute before the Court gives its final decision"14. In its orders on provisional measures, the Court itself examines these two requirements together. Without irreparable prejudice, there can be no urgency.

10. For these reasons, it is my view that, in the facts and circumstances of the present case, the Court ought not to have exercised its power to indicate provisional measures under Article 41 of the Statute.

(Signed) Dalveer BHANDARI.

\section{ENDNOTES}

1 Qatar's Application instituting proceedings, p. 16, para. 22.

2 CR 2018/13, p. 63, para. 25 (Shaw); ibid., p. 64, para. 26 (Shaw); CR 2018/15, p. 39, para. 12 (Shaw).

$3 \quad$ Nuclear Tests (Australia v. France), Judgment, I.C.J. Reports 1974 , p. 267, para. 43.

$4 \quad$ Nuclear Tests (New Zealand v. France), Judgment, I.C.J. Reports 1974, p. 467, para. 46.

5 Maritime Dispute (Peru v. Chile), Judgment, I.C.J. Reports 2014 , p. 65, para. 78 .

6 Questions relating to the Obligation to Prosecute or Extradite (Belgium v. Senegal), Provisional Measures, Order of 28 May 2009, I.C.J. Reports 2009, p. 154, para. 68.

$7 \quad$ Ibid., p. 155, para. 72.

8 Questions relating to the Seizure and Detention of Certain Documents and Data (Timor-Leste v. Australia), Provisional Measures, Order of 3 March 2014, I.C.J. Reports 2014, p. 156 , para. 38 .

$9 \quad$ Ibid., p. 158, para. 46.

10 United Nations, Treaty Series (UNTS), Vol. 1833, p. 3.

11 Land Reclamation by Singapore in and around the Straits of Johor (Malaysia v. Singapore), Provisional Measures,
Order of 8 October 2003, ITLOS Reports 2003, p. 24, para. 85 .

12 Ibid., p. 25, para. 88 .

13 Ibid., pp. 26-28, para. 106.

14 Questions relating to the Obligation to Prosecute or Extradite (Belgium v. Senegal), Provisional measures, Order of 28 May 2009, I.C.J. Reports 2009, p. 152, para. 62; Certain Activities Carried Out by Nicaragua in the Border Area (Costa Rica v. Nicaragua), Provisional Measures, Order of 8 March 2011, I.C.J. Reports 2011 (I), p. 21, para. 64; Questions relating to the Seizure and Detention of Certain Documents and Data (Timor-Leste v. Australia), Provisional Measures, Order of 3 March 2014, I.C.J. Reports 2014, p. 154, para. 32; Immunities and Criminal Proceedings (Equatorial Guinea v. France), Provisional Measures, Order of 7 December 2016, I.C.J. Reports 2016 (II), p. 1168, para. 83; Application of the International Convention on the Suppression of the Financing of Terrorism and of the International Convention on the Elimination of All Forms of Racial Discrimination (Ukraine v. Russian Federation), Provisional Measures, Order of 19 April 2017, I.C.J. Reports 2017, p. 136, para. 89; Jadhav (India v. Pakistan), Provisional Measures, Order of 18 May 2017, I.C.J. Reports 2017, p. 243, para. 50. 


\section{DISSENTING OPINION OF JUDGE CRAWFORD}

Insufficient evidence of real and imminent risk of irreparable prejudice - Statement by the UAE on 5 July 2018 Qatari citizens resident in the UAE officially permitted to continue to reside in the UAE - Hotline to receive applications by Qataris for entry clearance into the UAE - Evidence that Qataris have been entering the UAE and are being granted permits to do so - Risk of prejudice to rights flowed from the fact that Qataris were outside the UAE - Conditions for the indication of provisional measures not satisfied.

1. Qatar's request for provisional measures faces two principal difficulties, one legal, the other evidential. The legal difficulty is that Article 1 of the International Convention on the Elimination of All Forms of Racial Discrimination (CERD) distinguishes on its face between discrimination on grounds of national origin (equated to racial discrimination and prohibited per se) and differentiation on grounds of nationality (not prohibited as such). Moreover, that distinction finds its reflection in widespread State practice giving preferences to nationals of some countries over others in matters such as the rights to enter or to reside, entitlement to social security, university fees and many other things, in peace and during armed conflict. Prima facie at least, the UAE measures at issue here, deriving from the Statement of 5 June 2017, target Qataris on account of their present nationality, not their national origin. This does not mean that collective expulsion of persons of a certain nationality is lawful under international law; it is not. It is simply that it is not apparently covered by the CERD, the only basis for jurisdiction relied on by Qatar.

2. The factual difficulty is that it is not clear from the evidence that the measures announced against Qatari nationals on 5 June 2017 are still in effect, or that any of the measures that are in effect could cause irreparable prejudice to the rights which are the subject of these judicial proceedings.

3. The UAE Ministry of Foreign Affairs and International Cooperation announced in its Statement of 5 June 2017 that it was taking "measures that are necessary for safeguarding the interests" of the Gulf Cooperation Council States. One of the measures, announced in paragraph 2 of the Statement, was:

"Preventing Qatari nationals from entering the UAE or crossing its points of entry, giving Qatari residents and visitors in the UAE 14 days to leave the country for precautionary security reasons. The UAE nationals are likewise banned from traveling to or staying in Qatar or transiting through its territories."

4. Unlike the inter-State measures (closure of UAE airspace and seaports, etc.) set out in the Statement, it appears that no legislative or administrative action was taken to give effect to paragraph 2. The UAE's Agent stated in oral argument that no Qataris were deported or expelled pursuant to paragraph $2^{1}$. Qatar did not contradict this statement, although it argued that the Statement of 5 June 2017 itself amounted to an "order of expulsion".

5. However that may be, paragraph 2 stood as a statement of policy and it appears that a significant number of Qataris left the UAE on the strength of the Statement. To evidence this departure, Qatar presented a number of reports by national and international human rights organizations. A report by the Office of the United Nations High Commissioner for Human Rights noted that Qataris previously resident in the UAE had left the UAE following the Statement of June 2017, leaving behind families, businesses, employment, property and studies ${ }^{3}$. Further reports contain accounts of interviews with Qataris who had similarly left the UAE ${ }^{4}$. Overall the Qatari National Human Rights Committee estimates that it received 1,052 complaints in relation to the impact of the Statement of 5 June 2017, in the period to May $2018^{5}$. Many of these complaints were from individuals in mixed Qatari-Emirati marriages who insisted they were no longer able to live with their family members due to the measures contained in the Statement.

6. On 11 June 2017 the Ministry of Interior of the UAE set up a hotline to assist with the "humanitarian circumstances of Emirati-Qatari joint families", specifically to provide a procedure through which individuals separated from their families could apply for a permit to enter the UAE ${ }^{6}$. The UAE supplied evidence that of 1,390 requests for permits, 1,378 have been approved ${ }^{7}$. Qatar argued that approvals for Qataris to enter the UAE were temporary and needed to be sought for every proposed entry into the $\mathrm{UAE}^{8}$. Qatar further described the hotline as a "police security channel" provided by the Abu Dhabi police ${ }^{9}$. In this respect there is evidence that some individuals are 
wary of contacting the hotline because they are worried that it will be used to identify Qataris who have not returned to $\operatorname{Qatar}^{10}$.

7. Of those Qatari nationals who left the UAE, a significant number have returned to the UAE. The UAE's Agent stated that thousands of applications by Qataris for permits to enter the UAE have been approved, and that Qatari nationals have entered and exited the UAE on over 8,000 occasions, since June $2017^{11}$.

8. Many of the consequences of the Statement of June 2017 (family separation, difficulties in accessing property and courts, access to education and transcripts, and access to medical care) appear to have flowed from the fact that Qataris were located outside the UAE, rather than from deliberate policy - though these consequences were unfortunate and harmful to those concerned. consequences in July 2018. Most of the reports by national and international human rights organizations submitted by Qatar relate to the period June to August $2017^{12}$. While Qatar has provided a recent (fifth) report by its National Human Rights Committee, 896 of the 1,052 complaints received by the Committee in the period June 2017 to May 2018 had already been received by the end of August 2017, according to an earlier (third) report by the Committee ${ }^{13}$. The most recent (fifth) report by Qatar's National Human Rights Committee reiterates findings of earlier reports by other human rights organizations, without specifically identifying cases of forced departures of Qataris from the UAE that occurred in recent months ${ }^{14}$.

10. At the end of the oral hearings, I asked the Parties (a) whether the UAE's Statement of 5 June 2017, and in particular its paragraph 2, was still in effect and (b) whether the UAE had made any further announcement clarifying that Qataris residing in the UAE could elect to stay in the UAE. The UAE responded that the Statement had been issued by the Ministry of Foreign Affairs and International Cooperation, which did not have the legislative authority to establish the measures set out in the Statement. The UAE maintained therefore that there was no need for an announcement clarifying the entry and residence requirements applicable to Qatari nationals in the UAE ${ }^{15}$.

11. Qatar on the other hand contended that the UAE has failed to disavow the Statement of 5 June 2017 and that the policy reflected in the Statement continues to have a detrimental effect on Qataris. Qatar maintains that the continuing situation has not been resolved and necessitates the indication of provisional measures ${ }^{16}$.

12. Despite its response to my question, the UAE Ministry of Foreign Affairs and International Cooperation did issue an official Statement clarifying to some extent the entry and residence requirements applicable to Qataris in the UAE on 5 July 2018. That Statement is publically available on the website of the Ministry and contains the following:

"Since its announcement on June 5, 2017 . . the UAE has instituted a requirement for all Qatari citizens overseas to obtain prior permission for entry into the UAE. Permission may be granted for a limited-duration period, at the discretion of the UAE government.

The UAE Ministry of Foreign Affairs and International Cooperation wishes to confirm that Qatari citizens already resident in the UAE need not apply for permission to continue residence in the UAE. However, all Qatari citizens resident in the UAE are encouraged to obtain prior permission for re-entry into UAE territory.

All applications for entry clearance may be made through the telephone hotline announced on June 11, 2017."

13. It is established that the power of the Court to indicate provisional measures will be exercised only if there is urgency, in the sense that there is a real and imminent risk that irreparable prejudice will be caused to the rights in dispute before the Court gives its final decision ${ }^{17}$. The power of the Court to indicate provisional measures has as its object to ensure that such prejudice does not occur ${ }^{18}$.

14. The Court accepts that certain rights in question in these proceedings are of such a nature that prejudice to them is capable of causing irreparable harm (Order, para. 67). I do not disagree with this general statement. However, the Court fails to identify any evidence to support the further statement that the situation of Qataris residing in the UAE prior to 5 June 2017 appears to remain vulnerable with regard to their rights under Article 5 of the CERD. Most importantly, the UAE's Statement of 5 July 2018 is not mentioned. The UAE's recent Statement clarifies the legal 
position of Qataris living in the UAE, namely that they "need not apply for permission to continue residence in the UAE". The Statement further clarifies that Qataris can apply for entry clearance to the UAE via a hotline.

15. The further announcement in the UAE Statement of 5 July 2018 that applications for entry clearance may be made via the telephone hotline is supported by evidence that Qataris have entered or exited the UAE more than 8,000 times since June 2017 and that over 1,300 applications via the hotline system to enter the UAE have been granted (see above paragraphs 6-7). This evidence is again not dealt with by the Court.

16. Whilst there can be no doubt that the process for Qatari nationals seeking to enter the UAE has become more difficult, the state of affairs confirmed by the evidence before the Court, including the Statement of 5 July 2018, does not warrant a finding that there is a real and imminent risk that irreparable harm will be caused to the rights in dispute before the Court gives its final decision on the merits, unless measures are ordered. The risks that the Court seeks to curb through the provisional measures ordered have been to a large extent removed. The Court cannot ignore developments in this case since the request for the indication of provisional measures. One role of the Court is the peaceful settlement of disputes and if States are willing to address problems through actions or commitments, that is to be encouraged.

17. In view of the conclusion that there is no risk of irreparable prejudice in this case, it is unnecessary to consider the legal question identified in paragraph 1 of this opinion, viz., whether the UAE's Statement of 5 June 2017 plausibly implicates rights under the CERD as invoked by Qatar, which equated national origin with present nationality. Qatar's request for the indication of provisional measures fails on the facts.

18. Finally, I note that the provisional measures ordered by the Court are in themselves not objectionable. It is clear that the situation of Qataris still residing in the UAE, or wishing to travel to the UAE, became more difficult after 5 June 2017 and I trust that any remaining difficulties will be alleviated by the imposition of these measures by the Court. However, the legal requirements for the indication of provisional measures are binding. In this case, the requirement of irreparable prejudice and urgency is not met.

(Signed) James CRAWFORD.

\section{ENDNOTES}

1 CR 2018/13, p. 12, para. 11 (Alnowais).

2 CR 2018/14, p. 35, para. 19 (Goldsmith).

3 Office of the United Nations High Commissioner for Human Rights (OHCHR), Technical Mission to the State of Qatar, Report on the impact of the Gulf Crisis on human rights, December 2017, p. 5 (Application of Qatar, hereinafter "AQ", Ann. 16).

4 See for example, Human Rights Watch (HRW), Qatar: Isolation causing rights abuses, 12 July 2017, p. 7 (AQ, Ann. 10); Qatar's National Human Rights Committee (NHRC), 100 days under the blockade: Third report on human rights violations caused by the blockade imposed on the State of Qatar, 30 Aug. 2017, p. 7 (AQ, Ann. 12); NHRC, 6 months of violations: The fourth general report on the violations of human rights arising from the blockade on the State of Qatar, 5 Dec. 2017, p. 7 (AQ, Ann. 17).

5 NHRC, Fifth general report. Continuation of human rights violations: A year of the blockade imposed on Qatar, June 2018, p. 13 (AQ, Ann. 22).

6 Exhibit 2 of the documents deposited by the UAE, 25 June 2018.

7 Exhibit 3 of the documents deposited by the UAE, 25 June 2018.
8 CR 2018/14, p. 37, para. 25 (Goldsmith).

9 CR 2018/14, p. 36, para. 22 (Goldsmith).

10 HRW, Qatar: Isolation causing rights abuses, p. 6 (AQ, Ann. 10).

11 CR 2018/13, p. 13, paras. 13-14 (Alnowais). The UAE also stated that the number of Qataris living in the UAE now is "about the same as before 5 June 2017": CR 2018/15, p. 27, para. 6 (Buderi). The UAE Federal Authority for Identity and Citizenship estimated that as at 20 June 2018 there were 2,194 Qataris in the UAE: Exhibit 11, documents deposited by the UAE, 25 June 2018.

12 Namely, Anns. 5, 6, 8, 10, 11 and 12 of Qatar's Application.

13 NHRC, 100 days under the blockade: Third report on human rights violations caused by the blockade imposed on the State of Qatar, 30 Aug. 2017, p. 4 (AQ, Ann. 12). 997 of the total number of complaints had been received by December 2017, according to the Committee's fourth report, 5 Dec. 2017, p. 5 (AQ, Ann. 17).

14 NHRC, Fifth general report. Continuation of human rights violations: A year of the blockade imposed on Qatar, June 2018, pp. 15-16 (AQ, Ann. 22).

15 Response of the UAE to the question of Judge Crawford, 3 July 2018. 
16 Comments of Qatar on the written reply of the UAE, 5 July 2018.

17 See among many others, Application of the International Convention for the Suppression of the Financing of Terrorism and of the International Convention on the Elimination of All Forms of Racial Discrimination (Ukraine v. Russian Federation), Provisional Measures, Order of 19 April 2017, I.C.J. Reports 2017, p. 136, para. 89, quoting Immunities and
Criminal Proceedings (Equatorial Guinea v. France), Provisional Measures, Order of 7 December 2016, I.C.J. Reports 2016 (II), p. 1168, para. 83.

18 Application of the International Convention on the Elimination of All Forms of Racial Discrimination (Georgia v. Russian Federation), Provisional Measures, Order of 15 October 2008, I.C.J. Reports 2008, p. 388, para. 118. 


\section{DISSENTING OPINION OF JUDGE SALAM}

\section{[Translation]}

1. I regret that I am unable to support the conclusions reached by the majority on the prima facie jurisdiction of the Court to indicate the provisional measures requested by Qatar, which seeks to found the Court's jurisdiction in this case on Article 22 of the International Convention on the Elimination of All Forms of Racial Discrimination (hereinafter "CERD”).

2. I am convinced that the Court does not have prima facie jurisdiction ratione materiae, in so far as the dispute between the Parties does not appear to concern the interpretation or application of CERD. It is clear from Article 1 of CERD that this Convention applies to "any distinction, exclusion, restriction or preference based on race, colour, descent, or national or ethnic origin". There is, however, no mention of discrimination on the basis of "nationality", the object of the Applicant's complaints.

3. Moreover, when I read that provision in the light of Article 31 of the 1969 Vienna Convention on the Law of Treaties, which calls for a treaty to be "interpreted in good faith in accordance with the ordinary meaning to be given to the terms of the treaty in their context and in the light of its object and purpose", I feel bound to make the following observations:

a) the terms "national or ethnic origin" used in the Convention differ in their ordinary meaning to the term nationality.

b) As regards context, CERD was adopted against a historical background of decolonization and postdecolonization and was part of that effort to eliminate all forms of discrimination and racial segregation. Indeed, its Preamble states:

"Considering that the United Nations has condemned colonialism and all practices of segregation and discrimination associated therewith, in whatever form and wherever they exist, and that the Declaration on the Granting of Independence to Colonial Countries and Peoples of 14 December 1960 (General Assembly resolution 1514 (XV)) has affirmed and solemnly proclaimed the necessity of bringing them to a speedy and unconditional end,

Convinced that any doctrine of superiority based on racial differentiation is scientifically false, morally condemnable, socially unjust and dangerous, and that there is no justification for racial discrimination, in theory or in practice, anywhere,

Alarmed by manifestations of racial discrimination still in evidence in some areas of the world and by governmental policies based on racial superiority or hatred, such as policies of apartheid, segregation or separation."

c) The aim of CERD is thus to bring an end, in the decolonization and post-decolonization period, to all manifestations and governmental policies of discrimination based on racial superiority or hatred; it does not concern questions relating to nationality.

d) It is thus forms of racial discrimination that constitute the specific object of the Convention, and not any form of discrimination in general. Otherwise, reference would have been made to other types of serious discrimination based on a marker of a group's identity, such as religion, which is not the case here. Moreover, there are other international instruments which address questions relating to nationality, or discrimination in general such as the Universal Declaration of Human Rights and the two international covenants of $1966^{1}$. 
4. Furthermore, I would note that in the case concerning the Application of the International Convention for the Suppression of the Financing of Terrorism and of the International Convention on the Elimination of All Forms of Racial Discrimination (Ukraine v. Russian Federation), the dispute related to the question of racial discrimination against Crimean Tatars and "ethnic Ukrainians" (not Ukrainian nationals) in Crimea (Provisional Measures, Order of 19 April 2017, I.C.J. Reports 2017, p. 120, para. 37). Similarly, in the case concerning the Application of the International Convention on the Elimination of All Forms of Racial Discrimination (Georgia v. Russian Federation), the parties disagreed as to whether the events which took place in South Ossetia and Abkhazia involved racial discrimination of "ethnic Georgians" (and not Georgian nationals) living in those regions (Provisional Measures, Order of 15 October 2008, I.C.J. Reports 2008, p. 387, para. 111). The Court has thus only had occasion to rule on cases concerning discrimination based on ethnic origin, not "national origin", and has therefore not had to address the question whether this notion is distinct from that of "nationality".

5. This question of the distinction between "nationality" and "national origin" should not, in my view, admit of any confusion. They are two different notions. An example that clearly illustrates this difference is the well-known case of American citizens of Japanese origin who were incarcerated following the attack on Pearl Harbor during the Second World War. Despite having American nationality, these citizens were subject to racial discrimination based on their "national origin", not their nationality, and were rounded up and held in "War Relocation Camps"2. A similar type of discrimination based on "national origin" also affected a large number of individuals of German origin, regardless of their nationality at that time, in several countries after both the First and Second World Wars.

6. I would also point out that the distinction to be drawn between "nationality" and "national origin" is confirmed by the travaux préparatoires of CERD, particularly the proposed amendments to the wording of Article $1^{3}$.

7. In any event, had States wanted to say "nationality" rather than "national origin" in Article 1 of CERD, they could have done so. Likewise, they could have used the wording "nationality and national origin" had they intended to include both categories, which they did not do.

8. I would further note that, regardless of the "great weight" that should be ascribed to the work of an "independent body" such as the CERD Committee (see Ahmadou Sadio Diallo (Republic of Guinea v. Democratic Republic of the Congo), Merits, Judgment, I.C.J. Reports 2010 (II), p. 664, para. 66), the fact remains that the recommendations of that Committee cannot be considered to be an expression of a subsequent practice of the parties to CERD (in the sense of Article 31, paragraph 3 (b), of the 1969 Vienna Convention on the Law of Treaties).

9. In conclusion, although in my opinion the dispute between the Parties does not fall within the scope of CERD, I would note that in the case concerning the Legality of Use of Force (Yugoslavia v. United Kingdom), while the Court found that it lacked prima facie jurisdiction to entertain Yugoslavia's Application and "[could not] therefore indicate any provisional measure whatsoever" (Provisional Measures, Order of 2 June 1999, I.C.J. Reports 1999 (II), p. 839, para. 37), it nonetheless pointed out that "whether or not States accept the jurisdiction of the Court, they remain in any event responsible for acts attributable to them that violate international law, including humanitarian law" (ibid., para. 40). With that in mind, it requested that the parties "take care not to aggravate or extend the dispute" (ibid., para. 41). The Court adopted the same approach in the case concerning Armed Activities on the Territory of the Congo (New Application: 2002) (Democratic Republic of the Congo v. Rwanda): while also finding in this case that it did not have prima facie jurisdiction to indicate provisional measures (Provisional Measures, Order of 10 July 2002, I.C.J. Reports 2002, p. 249, para. 89), the Court stressed "the necessity for the Parties to these proceedings to use their influence to prevent the repeated grave violations of human rights and international humanitarian law which have been observed even recently" (ibid., para. 93).

10. By the same token, and taking account of Qatar's claim that Qataris residing in the United Arab Emirates have been in a vulnerable situation since 5 June 2017, although I believe that the Court should have found that it lacked prima facie jurisdiction to indicate provisional measures, this would not have prevented it from underlining, in its reasoning, the need for the Parties not to aggravate or extend the dispute and to ensure the prevention of any human rights violations. 
11. The conclusion I have reached makes it unnecessary for me to address the other conditions mentioned in Article 22 of CERD.

(Signed) Nawaf SALAM.

\section{ENDNOTES}

1 See, in particular, Article 13 of the International Covenant on Civil and Political Rights.

2 For background on this matter, see the report of the US Congress Commission on Wartime Relocation and Internment of Civilians (CWRIC), published on 24 February 1983 and entitled Personal Justice Denied (https://www.archives.gov/ research/japanese-americans/justice-denied).

3 See, among others, UN docs. A/C.3/SR.1304, A/C.3/SR.130 and $\mathrm{A} / 6181$. 


\section{DISSENTING OPINION OF JUDGE $A D$ HOC COT}

\section{[Translation]}

Vote against the operative part - Prejudgment of the question on the merits - Identity between the request for the indication of provisional measures and the claims on the merits - Existence of irreparable prejudice - Imminent risk - Unnecessary Order - Presumption of good faith at the provisional measures stage — Length of time between this Order and the next phase of the proceedings.

\section{INTRODUCTION}

1. To my great regret, I voted against the operative part of today's Order indicating provisional measures. I would therefore like to explain in particular why, in my view, the request in question does not satisfy the requirement of imminent risk of irreparable prejudice and why this Order is not necessary for the settlement of the dispute.

\section{THE PRESENT PROCEEDINGS MUST NOT PREJUDGE THE QUESTION ON THE MERITS}

2. In provisional measures proceedings, the applicant must not prejudge the question on the merits (A). Nor should the request for the indication of provisional measures itself prejudge the question relating to the merits (B).

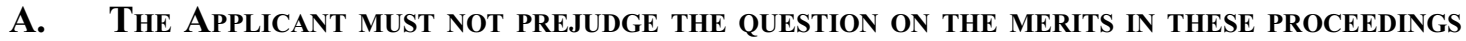

3. It is customary in an order indicating provisional measures for the Court to note in the following terms that its conclusion in that order in no way prejudges the merits of the case:

"The decision given in the present proceedings in no way prejudges the question of the jurisdiction of the Court to deal with the merits of the case or any questions relating to the admissibility of the Application or to the merits themselves." (See, for example, Jadhav Case (India v. Pakistan), Provisional Measures, Order of 18 May 2017, I.C.J. Reports 2017, p. 245, para. 60; Immunities and Criminal Proceedings (Equatorial Guinea v. France), Provisional Measures, Order of 7 December 2016, I.C.J. Reports 2016 (II), p. 1171, para. 98.)

4. Accordingly, pursuant to Practice Direction XI, which the President reads out at the opening of the public hearings, the parties must not enter into the merits of the case:

"In the oral pleadings on requests for the indication of provisional measures, the parties should limit themselves to what is relevant to the criteria for the indication of provisional measures as stipulated in the Statute, Rules and jurisprudence of the Court. They should not enter into the merits of the case beyond what is strictly necessary for that purpose."

5. The temptation for parties to enter into the merits of a case comes from the Court's jurisprudence, according to which the plausibility of the rights claimed by the applicant — which is inevitably linked to questions on the merits - must be demonstrated at the provisional measures stage. The respondent may also "have an interest in showing that the requesting State has failed to demonstrate a possibility of the existence of the right sought to be protected" (Separate Opinion of Judge Shahabuddeen, Passage through the Great Belt (Finland v. Denmark), Provisional Measures, Order of 29 July 1991, I.C.J. Reports 1991, p. 29). One proposed solution is to consider the standard of proof for plausibility as having a fairly low threshold, which, it is argued, would deter the parties from examining the merits of a claim (Separate Opinion of Judge Owada, Application of the International Convention for the Suppression of the Financing of Terrorism and of the International Convention on the Elimination of All Forms of Racial Discrimination (Ukraine v. Russian Federation), Provisional Measures, Order of 19 April 2017, I.C.J. Reports 2017, pp. 144145, para. 10, and p. 147, paras. 19-20). 
6. However, the Court's jurisprudence acknowledges that, in provisional measures proceedings involving rights under the International Convention on the Elimination of All Forms of Racial Discrimination (CERD), the question whether the alleged acts may constitute acts of racial discrimination can and must be examined:

"The Court notes that Articles 2 and 5 of CERD are intended to protect individuals from racial discrimination. Consequently, in the context of a request for the indication of provisional measures, a State party to CERD may avail itself of the rights under Articles 2 and 5 only if it is plausible that the acts complained of constitute acts of racial discrimination under the Convention" (Application of the International Convention for the Suppression of the Financing of Terrorism and of the International Convention on the Elimination of All Forms of Racial Discrimination (Ukraine v. Russian Federation), Provisional Measures, Order of 19 April 2017, I.C.J. Reports 2017, p. 135, para. 82).

7. Therefore, the Parties to this dispute may address the question of the interpretation and application of the Convention in so far as it is necessary to assess whether the alleged acts of the UAE are capable of constituting acts of racial discrimination.

8. That said, some of the arguments raised by Qatar during the oral proceedings appear to go beyond what is required for an examination of the plausibility of the rights claimed. In particular, it might be asked to what extent the detailed references to the general recommendations of the CERD Committee are needed here (see, for example, CR 2018/12, pp. 37-38, paras. 21-23, and p. 40, paras. 27-29 (Amirfar), and p. 47, paras. 3 and 5 (Klein)).

9. The Court does not have the power to prevent parties from engaging in such conduct during the hearings. There are no precedents of parties being penalized for adopting such a practice. One way to avoid prejudging the merits of a case is thus simply to ignore such arguments in the reasoning of the order indicating provisional measures. In the Ukraine v. Russian Federation case, for example, despite the detailed arguments put forward by the parties on the interpretation of two international conventions at issue, the Court generally confined itself to the wording of the relevant provisions of the conventions and reached its conclusion through simple and succinct reasoning (Application of the International Convention for the Suppression of the Financing of Terrorism and of the International Convention on the Elimination of All Forms of Racial Discrimination (Ukraine v. Russian Federation), Provisional Measures, Order of 19 April 2017, I.C.J. Reports 2017, pp. 131-132, paras. 74-76, and p. 135, paras. 81-83). In any event, the Parties to the present case were certainly not encouraged to address the interpretation of the Convention in detail.

\section{B. IDENTITY BETWEEN THE REQUEST FOR THE INDICATION OF PROVISIONAL MEASURES AND THE CLAIMS ON THE MERITS}

10. It is not only the parties' oral arguments which must not prejudge the merits of a case, the same applies to the request for the indication of provisional measures itself.

11. In the case concerning Construction of a Road in Costa Rica along the San Juan River (Nicaragua v. Costa Rica), the Court considered whether the provisional measures requested "prejudge[d] the merits of the case" and found that:

"this request is exactly the same as one of Nicaragua's claims on the merits contained at the end of its Application and Memorial in the present case. A decision by the Court to order Costa Rica to provide Nicaragua with such an Environmental Impact Assessment Study as well as technical reports at this stage of the proceedings would therefore amount to prejudging the Court's decision on the merits of the case" (Construction of a Road in Costa Rica along the San Juan River (Nicaragua v. Costa Rica); Certain Activities Carried Out by Nicaragua in the Border Area (Costa Rica v. Nicaragua), Provisional Measures, Order of 13 December 2013, I.C.J. Reports 2013, p. 404, para. 21). 
In other words, the Court found that, in principle, if a request for the indication of provisional measures "is exactly the same as one of [the] claims on the merits", it prejudges the merits of the case and must therefore be rejected.

12. In this case, there appear to be a number of overlaps between the claims made in the Application and the provisional measures sought by Qatar (compare, for example, paragraph 65 of the Application with paragraph 19 of the Request). At the same time, the terms used in the Request ("suspend", "cease and desist", "take necessary measures", etc.) appear to have been carefully chosen to suggest that the provisional measures sought are temporary and without permanent effect, and a different set of terms is used in the Application ("cease and revoke", "restore", "comply with", etc.). The question thus could have been asked whether these differences in terminology were sufficient to conclude that the provisional measures requested, were they to be indicated, would not prejudge the merits of the case.

\section{THE EXISTENCE OF IRREPARABLE PREJUDICE}

13. In light of its jurisprudence, the Court should have found that there was no imminent risk of irreparable prejudice in this case.

14. According to the Court's jurisprudence,

" $[t]$ he power of the Court to indicate provisional measures will be exercised only if there is urgency, in the sense that there is a real and imminent risk that irreparable prejudice will be caused to the rights in dispute before the Court gives its final decision" (see, for example, Jadhav Case (India v. Pakistan), Provisional Measures, Order of 18 May 2017, I.C.J. Reports 2017 , p. 243, para. 50).

15. Regarding the rights referred to in the Convention, the Court has noted, in particular, that the political, civil, economic, social and cultural rights mentioned in Article 5, paragraphs (b), (c), (d) and (e), of the Convention are of such a nature that prejudice to them is capable of causing irreparable harm (Application of the International Convention for the Suppression of the Financing of Terrorism and of the International Convention on the Elimination of All Forms of Racial Discrimination (Ukraine v. Russian Federation), Provisional Measures, Order of 19 April 2017, I.C.J. Reports 2017, p. 138, para. 96; Application of the International Convention on the Elimination of All Forms of Racial Discrimination (Georgia v. Russian Federation), Provisional Measures, Order of 15 October 2008, I.C.J. Reports 2008, p. 396, para. 142).

16. On another occasion, the Court found that there was a real risk of irreparable prejudice to the right in question if it were "not . . p possible to restore the situation to the status quo ante" (Immunities and Criminal Proceedings (Equatorial Guinea v. France), Provisional Measures, Order of 7 December 2016, I.C.J. Reports 2016 (II), p. 1169, para. 90).

17. I am inclined to think that, even if the underlying facts were duly established, the following rights in respect of which Qatar has sought provisional measures are not of such a nature that prejudice to them is capable of causing irreparable harm.

18. As regards the right not to be subject to racial discrimination (Arts. 2 and 4) and the right to freedom of opinion and expression (Art. 5 (d) (viii)), the status quo ante, in which Qatari nationals residing in the UAE were not the subject of hatred, and "sympathy" towards Qataris was not a crime, can, at least in theory, be restored. It is also noted that the Respondent contests this claim, contending that "[t]he statement of the Attorney General is ... not a law" (CR 2018/13, p. 65, para. 35 (Shaw)).

19. Concerning the right to work (Art. 5 (e) (i)) and the right to own property (Art. 5 (d) (v)), the status quo ante, in which Qatari nationals residing in the UAE could work and enjoy their property, can, theoretically, be restored, if the measure prohibiting Qataris entry to the UAE is lifted.

20. With respect to the right to equal treatment before tribunals (Art. $5(a)$ ) and the right to effective protection and remedies (Art. 6), while their absence may cause prejudice to other rights capable of causing irreparable harm, 
the right of Qatari nationals in the UAE to effective protection and remedies through UAE courts can, as such, theoretically be restored.

21. However, the Court has found today that prejudice to those rights before tribunals, as well as to the right to family and the right to education and training, may be irreparable (para. 69 of the Order). I do not agree with this finding; moreover, the Court's reasoning fails to consider whether such prejudice, even if it were irreparable, is "imminent".

\section{IMMINENT RISK}

22. It goes without saying that the irreparable nature of the prejudice caused to these rights is not on a par with the harm caused by the execution of the death penalty or the performance of a nuclear test. Furthermore, examining the other aspect of the third condition for the indication of provisional measures may lead the Court to conclude that the alleged risk is not imminent.

23. With regard to the lives of UAE-Qatari mixed families, although the long-term separation of a family may have an irreparable effect on its unity and integrity, that effect is unlikely to become permanent in the few years before the Court renders its final decision. In other words, it can be concluded that the risk of prejudice to this right, even if it were irreparable, is not imminent.

24. As regards the right to education and training, it is to be noted that the Respondent has presented evidence that the Emirati authorities have asked all post-secondary institutions in the UAE to monitor the situation of Qatari students (CR 2018/13, p. 69, para. 51 (Shaw)). Since the UAE authorities have taken measures to remedy the situation, it may be concluded or at least presumed that, even if it existed, the risk of irreparable prejudice to students is not imminent.

25. Lastly, regarding the right to public health and medical care (Art. 5 (e) (iv)), the evidence adduced by Qatar (OHCHR Technical Mission Report, Ann. 16 to the Application, paras. 43-44) shows that patients who were forced to leave the UAE subsequently received medical treatment in other countries, such as Germany, Turkey and Kuwait. Although some inconvenience may have been caused to those patients, this account suggests that, even if it existed, the risk of irreparable prejudice to them is not imminent.

\section{THE ORDER IS UNNECESSARY}

\section{A. The PResumption of goOd faith at the Provisional Measures Stage}

26. I am concerned that this Order indicating provisional measures is not only unnecessary but counter-productive to the settlement of the dispute, since the Court's conclusion on the risk of irreparable prejudice runs counter to the principle of good faith in public international law. This principle finds expression in Article 26 of the 1969 Vienna Convention on the Law of Treaties, which provides: "Every treaty in force is binding upon the parties to it and must be performed by them in good faith." It is also set forth in Article 2, paragraph 2, of the Charter of the United Nations, which is reflected in the declaration on friendly relations between States (resolution 2625 (XXV) adopted by the General Assembly on 24 October 1970).

27. This fundamental principle not only requires the parties to an international convention to fulfil their international obligations in good faith, it also requires international courts to handle with care cases in which the honour of a State is at issue. In other words, the presumption of good faith prevents a State's honour from being impugned lightly. This presumption, which promotes stability in international dealings and good relations, is invariably important in helping to maintain and reinforce States' confidence in the judicial settlement of disputes, where referral to the courts rests on the consent of the parties to the dispute (Robert Kolb, La bonne foi en droit international public, PUF, 2000, p. 126). It follows, a fortiori, that this principle should apply, mutatis mutandis, even at the provisional measures stage, when the Court must decide whether to make an order promptly, prior to its final determination on jurisdiction. Even if the present proceedings do not prejudge the question of the Court's jurisdiction to deal with the merits of the 
case, or the questions on the merits themselves, the separate consideration mentioned above requires the principle of good faith to be applied when examining the request for the indication of provisional measures.

28. International jurisprudence on the subject shows that this principle gives rise to the theory that good faith must be presumed (Interpretation of Peace Treaties with Bulgaria, Hungary and Romania, Second Phase, Advisory Opinion, I.C.J. Reports 1950, p. 229) and bad faith must not be presumed (United Nations, Tacna-Arica question (Chile, Peru), Award of 4 March 1925, RIAA, Vol. II, p. 930; Affaire du Lac Lanoux (Spain/France), Award of 16 November 1956, RIAA, Vol. XII, p. 305). In any event, one of the consequences of this notion is that it incumbent on the party which claims that the other has violated the principle of good faith to prove that claim (Certain German Interests in Polish Upper Silesia, Merits, Judgment No. 7, 1926, P.C.I.J., Series A, No. 7, p. 30). This rule regarding the burden of proof also applies at the provisional measures stage, where it is the applicant who must prove that there is a real and imminent risk of irreparable prejudice to the rights it claims (Construction of a Road in Costa Rica along the San Juan River (Nicaragua v. Costa Rica); Certain Activities carried out by Nicaragua in the Border Area (Costa Rica v. Nicaragua), Provisional Measures, Order of 13 December 2013, I.C.J. Reports 2013, p. 407, para. 34). The temporary nature of an order indicating provisional measures should not remove this burden from the applicant.

29. In my opinion, the evidence presented to the Court in these proceedings does not demonstrate that the risk of prejudice is "imminent", even if it were irreparable. This is implicitly illustrated in paragraphs 67 to 71 of today's Order, in which the Court, having concluded that the risk in question is one of irreparable prejudice, fails to ascertain whether that risk is "imminent". If the principle of good faith had been duly applied at this provisional measures stage, the Court would have been unable to confine itself to such a conclusion. That is particularly true where the UAE has shown genuine commitment towards its human rights obligations, as demonstrated by the arguments of its Agent (CR 2018/13, pp. 10-11, para. 3 (Alnowais); CR/2018/15, pp. 42, para. 2, and p. 44, para. 10 (Alnowais)) and the reply to the joint letter of the six Special Rapporteurs, in which the UAE states that "[ $\mathrm{t}]$ he United Arab Emirates continues to uphold those [human rights] treaties and is fully aware of its obligations and commitments in this regard" (HRC/NONE/2017/112 (18 Sept. 2017), p. 3; Ann. 14 of Qatar's Application). The Respondent should have been presumed to be acting in good faith.

\section{B. The Passage of TIME}

30. In my view, when examining the urgency of this case, the Court should have considered how much time would elapse between this Order and the next phase of the proceedings, be it preliminary objections or merits.

31. In the context of provisional measures proceedings, the notion of urgency is defined as a situation in which "irreparable prejudice [is] caused to the rights in dispute before the Court gives its final decision" (para. 61 of the Order; emphasis added). In this regard, time is generally considered as a baseline against which change can be measured in a given social context or period (David M. Engel, "Law, Time and Community", Law \& Society Review, Vol. 21, No. 4 (1987), pp. 606-607). Thus, the question whether a particular situation is urgent or not cannot be determined in the abstract; it must be considered in the light of a reasonably defined time frame. In the case of provisional measures, strictly speaking, the Court could not reach a decision without a fixed time frame or a sense of when the next phase of the proceedings will occur.

32. It would, of course, be too much to expect the Court to provide a precise timetable for a case at this initial stage. However, the apparent nature of a case may give a prima facie indication of its complexity, which would make it possible to predict how long proceedings might be expected to last. For example, if the nature of a case suggested a certain degree of complexity, the proceedings would be expected to last longer, and thus urgency would have to be assessed in relation to this longer time frame, during which social change might be more likely. On the other hand, if the case file did not suggest such complexity, a final decision might be expected relatively quickly, and thus urgency would have to be assessed with respect to this short time frame.

33. I am of the opinion that this case falls into the second category rather than the first, given the well-defined scope of the dispute as presented by the Applicant. It should also be noted that, even though Qatar's Application and 
request for provisional measures came out of the blue, the Respondent has presented its own view of the dispute, rather than simply rejecting the Applicant's allegations. In any event, the circumstances of the case suggest that it will not require a lengthy time frame, and that, therefore, urgency should have been assessed in relation to a short one. Given the nature of the rights in respect of which the Court has indicated provisional measures, they are less likely to be at risk of irreparable prejudice in the short interval before the case reaches the next phase.

(Signed) Jean-Pierre COT. 